
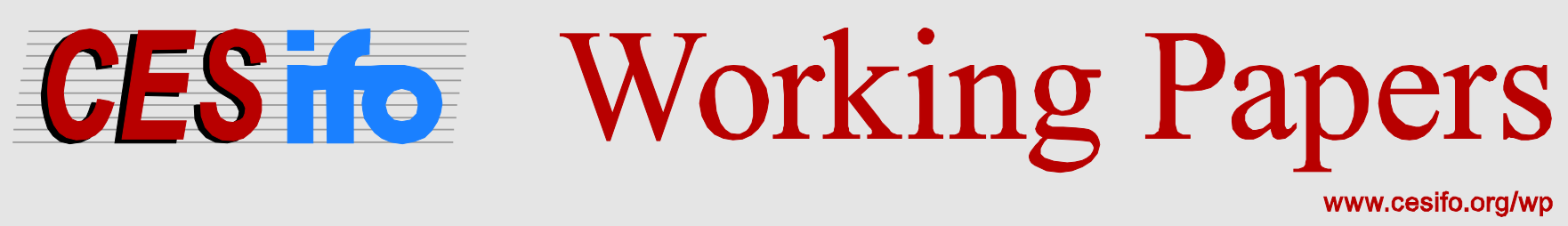

\title{
Tax Incentives and Business Investment: Evidence from German Bonus Depreciation
}

\author{
Sebastian Eichfelder \\ Kerstin Schneider
}
CESIFO WORKING PAPER NO. 4805
CATEGORY 1: PUBLIC FinANCE
MAY 2014
An electronic version of the paper may be downloaded
- from the SSRN website:
- from the RePEc website:
- from the CESifo website:
wWw.SSRN.com
www.RePEc.org
www.CESifo-group.org/wp

\section{CESifo}




\title{
Tax Incentives and Business Investment: Evidence from German Bonus Depreciation
}

\begin{abstract}
In this paper, we use an exogenous variation in tax regulations to analyze the impact of bonus depreciation programs on business investment. To promote economic convergence of Eastern and Western Germany after reunification, bonus depreciation tax incentives were granted for investments in Eastern Germany before 1999. Using business establishments in Western Germany as control group, we address the question if and to what extent these investment tax incentives boosted investment. In line with the theoretical literature, there is empirical evidence for strong and significant effects of the bonus depreciation program. The effects were stronger for long-lived capital goods, large businesses, and investments before the tax incentives were cut back in 1997. Moreover, there was a significant reduction in building investment in the year after the expiration of the program. This provides evidence for a 'shifting' of investment between periods with higher and lower benefits.
\end{abstract}

JEL-Code: G310, H250, H320.

Keywords: business taxes, bonus depreciation, investment, tax incentive, investment tax incentive.

\author{
Sebastian Eichfelder* \\ Otto-von-Guericke University \\ Universitätsplatz 2 \\ Germany - 39106 Magdeburg \\ sebastian.eichfelder@ovgu.de
}

Kerstin Schneider

Wuppertal University

Gaußstraße 20

Germany-42119 Wuppertal

schneider@wiwi.uni-wuppertal.de

*corresponding author

March 2014 


\section{Introduction}

For decades economists have been analyzing the question how tax incentive programs affect business investment. The question is important, as countercyclical fiscal policy - as in the 'financial crisis' 2008-2009 - typically relies on accelerated depreciations, investment tax credits, tax holidays and other forms of investment tax incentives. These policies typically coincide with a general economic downturn, making the measurement of the program outcomes complicated. This paper analyzes if and to what extent temporary partial expensing ('bonus depreciation') affects business investment. An important strength of our paper is that we can use Western Germany as a control group to analyze the impact of investment tax incentives in the eastern part of Germany.

After the collapse of communism in Eastern Europe, and German reunification, German policy was committed to supporting rapid economic convergence of the two parts of Germany. Speaking in July 1990, Chancellor Helmut Kohl made his famous promise of "flourishing landscapes". However, it did not take long to realize that convergence would not happen automatically, mainly because the industrial base in the territory of the former German Democratic Republic was not competitive (Sinn and Sinn, 1993). Hence, German policy decided on a tremendous tax incentive program to promote investments in Eastern Germany. The two main policy instruments were the Development Area Law (DAL) and the Investment Subsidy Law (ISL). Like bonus depreciation policies in the U.S. after 9/11 as well as after the economic crisis of 2008-2009 (Zwick and Mahon, 2014), DAL granted generous bonus depreciation for tax purposes of up to $50 \%$ of the investment. The second subsidy scheme, ISL, was launched in 1991 and ran out at the end of 2013. Unlike DAL, but like the investment tax credit in the U.S. (Hulse and Livingstone, 2010), ISL supported private investment by direct and tax-exempt subsidies.

According to neoclassic investment theory (Hall and Jorgenson, 1967; Hayashi, 1982), business taxes reduce the incentive for investment by increasing the user costs of capital. Conversely, tax incentive programs increase capital formation (Auerbach and Summers, 1979; Judd, 1985; Edge and Rudd, 2010). However, while there is empirical evidence for a negative impact of taxes on investment (e.g. Auerbach and Hassett, 1992; Devereux, Keen, and Schiantarelli, 1994; Cummins, Hassett, and Hubbard, 1996; Chirinko, Fazzari, and Meyer, 1999; Desai and Goolsbee, 2004; Chirinko and Wilson, 2008; Feld and Heckemeyer, 2011; Becker, Jacob, and Jacob, 2013), research on tax incentive programs like bonus depreciation is more limited and the evidence is mixed. 
Following House and Shapiro (2008), short-term tax incentive programs have an especially strong impact on long-term business investment, because investors can shift investments between periods to maximize benefits. Using aggregate data for different asset classes, the authors show that investment in assets for which the bonus incentives yield the greatest benefit - qualifying assets with long regular depreciation periods - did in fact respond to the incentives. However, House and Shapiro (2008) do not find significant evidence for an impact of the U.S. bonus depreciation on asset prices.

While there is research suggesting a positive effect of bonus depreciation regulations in the U.S. (Billings, Musazi, and Houston, 2008; Key, 2008; Edgerton, 2012; Park, 2012; Zwick and Mahon, 2014) and the Netherlands (Wielhouwer and Wiersma, 2013), the evidence is not fully conclusive. Using a difference-in-differences estimation strategy, Cohen and Cummins (2006) are not able to provide comprehensive empirical results. The same holds for Hulse and Livingstone (2010), who use Compustat data on the firm level. Using similar data and controlling for trends, Dauchy and Martinez (2008) obtain an almost negligible effect, with an implied investment elasticity of 0.03. In addition, Edgerton (2011) does not find a significant reaction of manufacturing prices to bonus depreciation policies.

There are several potential explanations for the mixed evidence. Recent bonus depreciation programs in the U.S. have been restricted to equipment. Taking into account that the present value of bonus depreciation benefits is higher for capital goods with long depreciation periods (Cohen, Hansen, and Hassett, 2002), while U.S. investment was largely on equipment with short depreciation periods (Desai and Goolsbee, 2004), the investment stimulus might have been too small to be empirically relevant. Furthermore, the effect of tax incentives is mitigated by tax losses and tax loss carryforwards (Edgerton, 2010). As bonus depreciation programs are typically initiated during a period of economic downturn, this might reduce the impact of this type of subsidy. In addition, the programs lasted only for a short period and were not anticipated (Hulse and Livingstone, 2010; Zwick and Mahon, 2014). Considering investment adjustment costs, the time might have been too short to adjust investments to benefit from the program. And finally, the lack of significant evidence could be partially driven by data quality. For example, studies based on Compustat data are not able to distinguish between long-lived capital goods and short-term assets on the firm level (Hulse and Livingstone, 2010; Zwick and Mahon, 2014).

In this paper, we use the German DAL to address the question if and to what extent accelerated depreciation programs affect business investment. Compared to previous research, 
the German setting has a number of advantages that make empirical analysis worthwhile. First of all, DAL was not limited to equipment investment, but also available for investments in structures with long depreciation periods. Thus, we expect stronger effects from the DAL program and can compare different asset types. Second, depreciation allowances in Western Germany were not affected by tax incentives during the time period studied. Thus, we can interpret DAL, which expired at the end of 1998, as a natural experiment, using establishments in the western states of Germany as a control group. Combined with state-level price indices, this also allows us to draw conclusions on the pricing effects of the subsidy. Third, all business investments in Eastern Germany qualified for the bonus depreciation program, which mitigates the problem of self-selection. Fourth, DAL was in place for eight years, leaving businesses enough time to adjust investment to that policy. Fifth, the long interval since the expiration of the program provides us with an extensive reference period and enables us to analyze investment shifting effects between the pre-DAL period and the post-DAL period.

Our paper provides the following contributions: We are the first to analyze bonus depreciation policies for the economic recovery of Eastern Germany. Using detailed establishment-level data, we confirm theoretical predictions and provide evidence for a very strong effect of DAL on building investment. Our analysis suggests, further, a positive but limited impact of bonus depreciation on state-level building prices. While average building investment volumes (including the price effect) were increased by $36.1 \%$, our estimate for the price effect as such is only $3.7 \%$. We can show that the impact of bonus depreciation was stronger for large businesses than for small ones. Thus, due to economies of scale in the tax compliance and tax planning process (Rego, 2003; Richardson and Lanis, 2007; Eichfelder and Schorn, 2012), tax incentives and other forms of subsidies might favor large firms compared to SMEs, and therefore affect competition between both groups of businesses. Finally, confirming theoretical research (House and Shapiro, 2008; Edge and Rudd, 2010), there is evidence that the expiration of DAL resulted in a decline in building investment in the following period. Therefore, our research implies that additional investment was partially driven by investment shifting between periods.

The paper is organized as follows: In Section 2, we describe the German tax incentives during the time period 1995-2008. Section 3 derives hypotheses for empirical analysis, and the data and empirical strategy are discussed in Section 4. Section 5 presents the results, and Section 6 concludes. Appendices A to D provide additional information about the data, the variables used, and the regression results of cross checks. 


\section{Development Area Law and Investment Subsidy Law}

Soon after German reunification in 1990, it became apparent that Eastern Germany would not develop as fast as had been hoped. Economic convergence of the two parts of Germany would not happen in the short term. Hence, fiscal policy was designed to increase incentives for private investment in Eastern Germany. While economists argue that subsidies to equipment investment can reduce tax distortions (Judd, 1999) and stimulate growth (De Long and Summers, 1991), German policy also subsidized investment in structures. This can be justified by the need perceived at the time for initial long-term investment in Eastern Germany. The two major programs of this policy were the Development Area Law (DAL) and the Investment Subsidy Law (ISL). DAL and ISL were among the most costly subsidies of the 1990s. In 1996 the DAL depreciation for business investment and ISL subsidy for equipment investment were the most important and third most important tax incentive programs, with tax revenue losses of $€ 4.7$ billion and $€ 1.3$ billion respectively. In the following we focus on the legal regulations for manufacturing industry.

After December 1990 DAL (German: Fördergebietsgesetz) bonus depreciation could be simply declared in the annual tax return for investments in the five eastern federal German states (Brandenburg, Mecklenburg-West Pomerania, Saxony, Saxony-Anhalt, Thuringia) and Berlin. In addition to regular tax depreciation, it allowed for a bonus depreciation of $50 \%$ of the invested amount. The bonus depreciation could be allocated over the first five years following the investment, provided that no other special depreciation schemes had been used. The program was planned to expire by the end of 1996. However, a prolongation until December 1998 was enacted in October 1995. The depreciation rate was reduced to $40 \%$ for investments in 1997 and 1998. The bonus depreciation was not restricted to specific branches or business types. It was available for movable assets (with the exception of aircraft) and investments in structures including the modernization of buildings.

The ISL (German: Investitionszulagengesetz) was enacted at the same time as DAL and ran out at the end of 2013. It granted direct, tax-exempt subsidies for businesses in the five eastern federal states and Berlin. The standard subsidy rate changed from 12\% in 1991 to 5\% for investments after June 1994. For businesses with no more than 250 staff members and investments of up to $€ 2.6$ million, the subsidy rate was $10 \%$. ISL was initially planned to expire at the same time as DAL. However, on August 18, 1997 the German legislator enacted ISL 1999, which extended the program until December 31, 2004. However, objections by the European Commission pursuant to European anti-subsidy regulations required a retroactive 
revision of the program by December 22, 1999. As a result, the exact funding criteria and funding rates for 1999 remained uncertain until the end of that year.

With ISL 1999 the general funding rate for investments in equipment and buildings was raised to $10 \%$. For firms with no more than 250 staff members (SMEs) there was a higher rate of $20 \%$ for equipment investment (not for buildings). These higher rates were thought to partially compensate for the expiration of DAL. However, due to European anti-subsidy regulations, these higher rates were only applicable to so-called initial investments (German: Erstinvestition), including the foundation or extension of a business establishment, major modifications of products and production methods, and the acquisition of a business that would otherwise have been liquidated. For other investments in new movable assets completed by the end of December 2002 the relevant rate was 5\% (10\% for SMEs). Further amendments of ISL 1999 resulted in an increase of funding rates to $12.5 \%$ (25\% for SMEs) for initial investments after December 1999.

The ISL assessment base was smaller and funding criteria were more rigorous than with DAL. Before 1999, ISL subsidies were restricted to new movable assets with some exceptions (no low-value assets, cars or aircraft). After 1999, ISL subsidies were expanded to investment in new structures, but only in the case of initial investments. ISL funding required a formal application, which implied a higher compliance burden for businesses. An overview of the most relevant regulations of both programs is given in Table 1.

[Table 1 about here]

Figure 1 shows the aggregate value of the DAL and ISL subsidies measured by annual losses of tax revenue as well as the present value of these subsidies. Note that the main effect of DAL is an interest-free loan to firms, as higher depreciations in earlier periods defer the tax burden to future periods. By contrast, ISL subsidies are cash-flow-based payments. Therefore, the present value of both benefits can be used to assess and compare the volume of the subsidies (for computational details see Appendix A). As shown in Figure 1, due to the expiration of DAL the annual value of the subsidies, as well as their present value, declined between 1997 and 1999.

[Figure 1 about here]

Therefore, we expect to see higher investments between 1995 and 1998 in the eastern states of Germany compared to the time after DAL had expired. Support for this conjecture comes from the price-adjusted investment index $(2000=100)$ for buildings and equipment in German 
manufacturing industry (Figure 2), which indicates that investment activity in the East declined, especially for building investment, after the expiration of DAL.

[Figure 2 about here]

\section{Theoretical framework and hypotheses}

The theoretical framework for the impact of tax policy on business investment goes back to Hall and Jorgenson (1967). According to their model, taxes and tax incentives have an impact on the effective cost of capital goods, expressed by the user costs of capital. Abstracting from adjustment costs, the user cost of capital can be described by

$$
C_{t}=\varphi_{t} \cdot T_{t} \cdot\left(\rho_{t}+\delta_{t}-E\left(\Delta \varphi_{t} / \varphi_{t}\right)\right)
$$

with the price level $\varphi_{t}$, the after-tax cost of funds (debt and equity) $\rho_{t}$, and the physical rate of depreciation $\delta_{t}$ at time t. $E\left(\Delta \varphi_{t} / \varphi_{t}\right)$ describes expected changes in the price of capital goods in the next period. Therefore, $\delta_{t}-E\left(\Delta \varphi_{t} / \varphi_{t}\right)$ is the expected net rate of depreciation (Auerbach, 1983). Tax effects are captured by the tax term

$$
T_{t}=\left(\frac{1-\tau_{t} \cdot Z_{t}-s_{t}}{1-\tau_{t}}\right)
$$

with the tax on profits denoted by $\tau_{t}$, the rate of direct subsidies (in our case ISL benefits) for capital investment by $s_{t}$, and the present value of depreciation allowances per $€$ invested by $Z_{t}$. Note that anticipated changes in tax regulations may have an impact on anticipated changes in the price level $E\left(\Delta \varphi_{t} / \varphi_{t}\right)$ (Cohen, Hansen, and Hassett, 2002). As we are analyzing the effect of taxes/subsidies in Eastern Germany relative to Western Germany, we will focus on the relative user cost of capital, $R C_{t}$, with

$$
R C_{t}=\frac{C_{t}^{E}}{C_{t}^{W}}=\frac{\varphi_{t}^{E} \cdot T_{t}^{E} \cdot\left(\rho_{t}^{E}+\delta_{t}^{E}-E\left(\Delta \varphi_{t}^{E} / \varphi_{t}^{E}\right)\right)}{\varphi_{t}^{W} \cdot T_{t}^{W} \cdot\left(\rho_{t}^{W}+\delta_{t}^{W}-E\left(\Delta \varphi_{t}^{W} / \varphi_{t}^{W}\right)\right)} .
$$

$C_{t}^{E}$ and $C_{t}^{W}$ denote the user cost of capital in Eastern Germany and Western Germany respectively. Simplifying (3), we assume that the physical rate of depreciation does not depend on the location of an asset, hence $\delta_{t}^{E}=\delta_{t}^{W}$. Moreover, we abstract from differences in 
the pre-tax price level and from differences in the after-tax cost of funds in both parts of Germany, hence $\varphi_{t}^{E} \approx \varphi_{t}^{W}$ and $\rho_{t}^{E} \approx \rho_{t}^{W}$. This leaves us with the effective relative tax burden of Eastern Germany versus Western Germany

$$
R T_{t}=\frac{1-\tau_{t}^{E} \cdot Z_{t}^{E}-z_{t}^{E}}{1-\tau_{t}^{W} \cdot Z_{t}^{W}-z_{t}^{W}} \cdot \frac{1-\tau_{t}^{W}}{1-\tau_{t}^{E}}
$$

Note that tax rates $\tau_{t}^{E}$ and $\tau_{t}^{W}$ need not to be identical, as we compute average tax rates for Eastern and Western German corporations and partnerships and also account for varying local business tax rates (German: Gewerbesteuerhebesätze). Clearly, smaller values of $R T_{t}$ indicate higher relative tax benefits or a lower tax burden for investments in Eastern Germany. In Table 2, we list $R T_{t}$ for six asset classes between 1995 and 2005 (for computational details see Appendix B). In the following periods (2006 to 2008), there are no relevant changes. Therefore, we abstain from reporting these results.

[Table 2 about here]

Table 2 shows a general tendency toward an increasing relative tax burden in Eastern Germany. This results from a reduction of the tax benefits in the eastern states, mainly driven by the expiration of DAL. However, there are exceptions to this rule. While we observe an increase in $R T_{t}$ for all classes of building investment (large firms and SMEs, initial investment and other investment), we find lower $R T_{t}$ values after the expiration of the DAL program in the case of fundable initial equipment investment, which is attributed to the generous funding of those investments under ISL. Moreover, the observed reduction of $R T_{t}$ for initial equipment investment is moderate in the case of large firms and more pronounced for SMEs. Thus, we expect the impact of the expiration of DAL to be stronger for building investment compared to equipment investment and stronger for equipment investment of large firms compared to equipment investment of SMEs. In sum, we hypothesize a generally higher level of investment activity before the expiration of the DAL program. ${ }^{1}$

Taking into account the increase in $R T_{t}$ for fundable and initial equipment investment, the average treatment effect on equipment is not entirely clear. However, additional arguments support a reduction in equipment investment after 1998. (1) The aggregate level of ISL subsidies for equipment investment following the expiration of DAL (€665m in 1999 and €891m in 2000) did not differ significantly from corresponding payments in preceding periods (€907m in 1997 and $€ 645 \mathrm{~m}$ in 1998). Thus, the impact of the high funding rates on initial investment should have been relatively small regarding average investment. (2) The German legislator initially intended not to prolong DAL and ISL. The extension of ISL in 1997 and thereafter was concluded by August 18, 1997. Therefore, the take-up of the high ISL 1999 subsidies for initial investment 
Hypothesis 1: DAL resulted in higher business investment in Eastern Germany compared to the following periods.

The literature argues that bonus depreciation programs are more relevant for capital goods with long regular depreciation periods (Cohen, Hansen, and Hassett, 2002; House and Shapiro, 2008). This is supported by the increase in the relative tax burden for building investment in the later years of our sampling period in Table 2. Therefore, we expect a stronger impact of the bonus depreciation program on building investment.

Hypothesis 2: DAL bonus depreciation had a particularly strong and positive effect on building investment.

Table 2 shows that the expiration of DAL was more relevant for the equipment investment of large firms than for that of SMEs. This follows from the higher ISL subsidy for the initial equipment investment of SMEs that compensated them for the loss of the DAL program (cf. Section 2). Hence, we would expect a stronger impact of DAL subsidies on the investments of large firms. Another argument for this hypothesis is that tax planning is costly, and marginal compliance and planning costs decrease as firm size increases (Gunz, MacNaughton, and Wensley, 1995; Rego, 2003; Richardson and Lanis, 2007; Eichfelder and Schorn, 2012). Therefore, larger firms should spend more resources on tax planning and the optimization of tax benefits. This fits well with Knittel (2007), who observes low take-up rates of the 2002 U.S. bonus depreciation by small businesses.

Hypothesis 3: The DAL effect on business investment was stronger for large firms.

Hypothesis 1 to Hypothesis 3 refer to the average DAL effect on Eastern German firms compared to the following periods. In addition, we formulate hypotheses to address investment-shifting activities. As has been noted earlier, the DAL bonus depreciation was reduced from 50\% in 1995 and 1996 to 40\% in 1997 and 1998. Furthermore, the first draft of ISL 1999 - which increased maximum funding rates - was decided in August 1997. Therefore, investments in 1997 and 1998 might have been affected by information on the prolongation of funding after 1999. Both arguments imply a smaller impact of DAL on investments in 1997 and 1998 compared to the preceding years.

required changes in investment plans, causing adjustment costs. (3) The European Commission did not accept the initial version of ISL 1999. Hence, there was high uncertainty about the increase in ISL maximum subsidy rates in 1999. (4) The German government concluded a major tax reform in 1999/2000/2001, reducing corporate income taxes. Therefore, the ex-post impact of bonus depreciation up to 1998 was even higher, as suggested by Table 2. 
Hypothesis 4: The DAL effect on business investment was stronger in 1995 and 1996 than in 1997 and 1998.

According to the model of Edge and Rudd (2010) an investment pothole in the period after the running out of a temporary subsidy program is likely if adjustment costs are low and prices are sticky. This fits well with House and Shapiro (2008), who argue that investments may be pulled forward in order to receive a higher benefit. Therefore, we expect a reduction of investment in the period following the expiration of DAL.

Hypothesis 5: The running out of DAL resulted in an investment pothole in 1999.

Another question to be addressed in this paper is the possibility of 'subsidy shopping'. If adjustment costs are low, investment may be shifted between business establishments in order to receive a higher benefit. In our data for German firms and establishments, adjustment costs should be related to the number of business establishments. For instance, adjustment costs are lower for business groups than for single establishment firms. Consequently, we expect business groups to be more strongly affected by the expiration of DAL.

Hypothesis 6: The DAL had a stronger impact on business groups with more than one establishment.

While it has been argued that investment tax incentives should not only affect real business investment but also the price level of corresponding capital goods, existing empirical studies do not provide conclusive evidence (House and Shapiro, 2008; Edgerton, 2011). So we add to the debate by considering the pricing effects of the German DAL program. As funding reduces the user cost of capital, there should be generally a positive impact of tax incentives on prices of investment goods. Taking further into account the limited impact of regional subsidies on prices of globally-traded investment goods like machines, our focus is on price effects on buildings.

Hypothesis 7: The DAL had a positive effect on prices for new buildings in Eastern Germany.

\section{Data and empirical strategy}

\subsection{Data}

Our analysis is based on the German AFID panel (German: Amtliche Firmendaten in Deutschland) for the manufacturing and mining industries, which includes a number of 
mandatory business surveys conducted by the German Federal Statistical Office and can be accessed by remote data processing (Malchin and Voshage, 2009). The main surveys in question, conducted between 1995 and 2008, are the Investment Survey and the Monthly Report. In addition, we also consider information of the Cost Structure Survey of Manufacturing and Mining Enterprises. ${ }^{2}$ The Investment Survey and the Monthly Report collect information on the universe of business establishments with at least 20 staff members in those industries. We also collected data on the district level (GDP per capita, population, unemployment rate) from the Regio-stat data base to control for regional economic conditions in the regression analysis. Hence, we have a unique firm panel covering the period between 1995 and 2008.

Compared to other firm panels like Compustat or AMADEUS, AFiD has advantages and disadvantages. Unlike accounting data, the Investment Survey provides very detailed information on different investment types, but has no explicit information on capital stock. Therefore, we estimate capital stock on the establishment level, using information from the Cost Structure Survey and extending the approach of Wagner (2010) (see Appendix C). An important advantage of our data is the detailed information it provides on equipment and building investment on the establishment level. Unlike earlier studies, we can estimate the impact of investment subsidies on both long-term and short-term capital goods of establishments in the eastern compared to the western states of Germany. Therefore, the data provides us with a powerful identification strategy. Unlike data based on accounting information (Compustat, AMADEUS), our data does not rely on the publications of individual firms, but on a census of all business establishments of the manufacturing and mining industries with at least 20 staff members. Participation in these business surveys is mandatory, so information gaps are limited to a small number of cases.

The data comprises 691,822 observations of business establishments between 1995 and 2008, which participated in the Investment Survey and the Monthly Report, and report both firm and establishment IDs. As a consequence of the special status of the Berlin area (see Table 1), we omit 13,394 observations on establishments located in the state of Berlin. Moreover, since our focus is on manufacturing industry, we do not account for 21,019 observations of mining companies. Finally, we omit a further 83,221 observations whose information on the primary variables of interest is incomplete.

2

German titles are as follows: Investitionserhebung bei Betrieben des Verarbeitenden Gewerbes sowie der Gewinnung von Steinen und Erden; Monatsbericht bei Betrieben des Verarbeitenden Gewerbes sowie der Gewinnung von Steinen und Erden; and Kostenstrukturerhebung bei Unternehmen des Verarbeitenden Gewerbes sowie der Gewinnung von Steinen und Erden. 
Our final sample thus comprises 574,188 observations for 68,396 manufacturing industry establishments. Due to mergers and acquisitions and other forms of restructuring, a single establishment may be part of more than firm over the time period studied. Table 3 summarizes the establishment data by region. Panel A reports the data for all observations, while panels B and C report descriptive statistics for the western (478,790 observations) and eastern German states (95,398 observations) respectively.

The data has been price-adjusted using the German producer price index for the manufacturing industry (cf. German Council of Economic Experts 2011, p. 409). When deflating equipment investment, we assume that prices in western and eastern states do not differ significantly from each other. This is justified by the high level of economic integration, implying low transportation and transaction costs for movable assets. Building prices, however, typically depend on local economic conditions. Hence, a regional subsidy (like bonus depreciation in Eastern Germany) might increase not only regional investment, but also regional prices (House and Shapiro, 2008; Edgerton, 2011). ${ }^{3}$ For that reason, we use statelevel building price indices for the manufacturing industry to calculate the price adjustment of building investment volumes. ${ }^{4}$

[Table 3 about here]

On average, price-adjusted gross investments (including zero investments) in Western Germany (€1,142.79 thousand) are slightly higher than in the eastern states (€995.97 thousand). That holds in particular for equipment investment, which accounts for a large fraction of gross investment. Investment in real estate is much smaller. The percentage of establishments with positive gross investment is quite high and does not vary considerably between both regions (86.91\% in the West and 85.59\% in the East). However, establishments in the East are more likely to invest in structures.

3 This argument does not hold for movable assets that are traded globally. Due to the limited size of the Eastern German economy, the impact of local subsidies on prices of globally traded capital goods will be small. Moreover, due to limited transaction and transportation costs, differences in prices for movable assets in Eastern and Western Germany are small as well. This is underlined by the fact that the German Federal Statistical Office does not provide region-specific price indices for these types of capital goods.

4 Corresponding price indices are provided by the statistical offices of ten major German states. The state of Berlin has been excluded from the data base. For the remaining five states (Bremen, Hamburg, MecklenburgWest Pomerania, Rhineland-Palatinate and Schleswig-Holstein), we rely on average building price indices for Western and Eastern Germany. These average price indices are calculated by the GDP-weighted average of the existing price indices for states in Western Germany (Baden-Württemberg, Bavaria, Hessen, Lower Saxony, North Rhine-Westphalia and Saarland) and Eastern Germany (Brandenburg, Saxony, Saxony-Anhalt and Thuringia). 
Business establishments in the East are smaller in terms of staff (large firms with more than 250 staff members), revenue and capital stock. Note that our estimates for $K_{i t-1}$ fit well with representative balance sheet information for the German manufacturing industry provided by the German Federal Bank (2012). In line with this representative balance sheet data, the ratio of revenue to capital stock in the eastern states is smaller than in the western states. Thus, if output is measured by sales revenue, establishments in the East seem to have been overcapitalized on average, provided that firms in both regions of Germany are working with the same technology. The lower fraction of foreign revenue indicates that businesses in the East are also less globalized. In addition, unemployment rates in the eastern states are higher and GDP-per-capita ratios are smaller than in the West.

\subsection{Empirical strategy}

For our empirical analysis, we interpret the expiration of DAL and the corresponding changes in funding policy by the end of 1998 as a natural experiment. As the western states were not directly affected by these institutional changes, we may use them as a control group and identify the DAL effect by a difference-in-differences (DiD) estimator. A clear advantage of our setting is that DAL bonus depreciation has been available for almost all manufacturing industry investment in the eastern German states. Self-selection, which is typically a major concern for the evaluation of subsidy programs, should therefore not be a serious problem.

Nevertheless, our identification strategy might be challenged by the fact that our treatment group (Eastern Germany) and our control group (Western Germany) are different in a number of respects (e.g. GDP per capita, business size). To account for this objection we rely on a broadly based strategy. We test a number hypotheses outlined in Section 3 to identify and analyze the DAL effect. This allows for deeper insights compared to a simple average DiD estimate. Since investment behavior is driven by observed and unobserved variables, including firm-specific opportunities and regional economic conditions, we add a comprehensive set of control variables. We further exploit the panel structure and include establishment fixed effects, year fixed effects and industry-year fixed effects to account for unobserved characteristics and industry-specific shocks. The robustness checks consider additional control variables as well as variations of the control and treatment groups and confirm our baseline results (see Appendix D).

To test hypotheses 1 and 2, we estimate

$I_{i t}=\beta_{0}+\beta_{1} \cdot$ east $\cdot$ before $99+\gamma \cdot X_{i t}+\alpha_{i}+u_{i t} \cdot$ 
We use four alternative dependent variables $I_{i t}$ for investments of the establishment $i$ at time t. $I_{i t}$ can be measured by a dummy variable indicating whether a firm has invested or not (extensive margin). It can also be the logarithm of investment volume, given a non-zero investment (intensive margin). In both specifications, we distinguish between building investment and equipment investment. The average treatment effect of the variation in subsidy programs in the late 1990s is estimated by $\beta_{1}$, the coefficient of the interaction term of investments in Eastern Germany and the time dummy before99. To simplify our notation, we denote east - before99 by DiD. As we include year and establishment fixed effects, the dummy variables east and before99 are not explicitly included in the regression.

The idiosyncratic error term is denoted by $u_{i t}$ and the vector of control variables by $X_{i t}$. We consider establishment fixed effects, $\alpha_{i}$, to account for unobserved heterogeneity of the establishments. Economic conditions, industrial trends and general legal developments (like business cycles, interest rates and changes in tax laws) are captured by year fixed effects and industry-year fixed effects. In addition, we consider a number of structural variables on the establishment level, the district level and the trans-regional level.

On the establishment level, we control for the logarithm of the capital stock of the preceding period $K_{i t-1}$, which serves as a proxy for capital endowment. Like Zwick and Mahon (2014), our analysis is based on a regression on the logarithm of investment and not on investment scaled by capital stock. Therefore, our results can be interpreted as elasticities. In addition, we reduce potential measurement error in our dependent variable, as our information on $I_{i t}$ is more precise than information on $K_{i t}$. Note that controlling for $\log \left(K_{i t-1}\right)$ in a regression on $\log \left(I_{i t}\right)$ is in fact equivalent to a regression on $\log \left(I_{i t} / K_{i t-1}\right)$.

In addition, we measure the investment potential by the ratio of revenue of the current period to the capital stock of the previous period $R_{i t} / K_{i t-1}$, by the fraction of foreign sales and by the fraction of sales generated in manufacturing industry. The ratio $R_{i t} / K_{i t-1}$ can also be regarded as a measure for capital constraints, as revenue is positively correlated to cash flow and cash flow is a common proxy for capital constraints (Hadlock and Pierce, 2010). We expect a positive effect of these variables on business investment.

In addition, business investment might be driven by regional economic conditions. Therefore, we have enriched our data by information on the district level. In detail, we consider the 
unemployment rate (in percentage points), the logarithm of the price-adjusted GDP per capita and the logarithm of the population in a district. These variables account for major economic differences within the eastern and western states.

Since the German reunification process might have affected investment in both parts of Germany, we include variables on the trans-regional level (Eastern Germany and Western Germany). First of all, we account for the economic euphoria and overly optimistic expectations resulting from the downfall of communism and the reunification of Germany. Until the middle of the 1990s, forecasts of economic growth - and also realized GDP growth - in the East exceeded growth rates in the West. However, in the mid 1990s the dynamics changed, and expectations as well as growth rates in the eastern states went down. These macro-economic trends, including overly optimistic expectations, might have affected investment in manufacturing industry during the time period studied. Therefore, we include forecasting errors of economic growth in the following period (i.e. the near future) as a measure for 'East euphoria'. We expect this forecasting error to be positively correlated with investment. The forecasting error is measured as the difference between published GDP growth forecasts and realized GDP growth. ${ }^{5}$

Another explanation for differences in business investment in both parts of Germany could be an investment backlog in the East. While this should be generally accounted for by capital stocks and revenue to capital ratios on the establishment level, there could be asset-classspecific effects (for buildings or equipment) that are not captured by $K_{i t-1}$. Hence, we consider a lagged capital stock index for either buildings (in regressions on building investment) or equipment (in regressions on equipment investment) for the eastern and western states, based on representative balance sheet data in the manufacturing industry (German Federal Bank, 2012). The starting point of the index is one. Annual changes in the index are defined as the relative change of the relevant ratios of fixed assets (either buildings or equipment) to total assets in the representative balance sheet data. ${ }^{6}$

5 Growth forecasts have been collected from the annual reports of the major German research institutions published by the German Institute for Economic Research in Berlin (DIW Berlin). We use the earliest forecasts published by the weekly journal of that institute ("Wochenbericht des DIW Berlin").

6 To obtain values for the western states, we refer to German Federal Bank (2012), Table D 3. For eastern states we refer to German Federal Bank (2012), Table O 2. As the German Federal Bank (2012) does not provide representative balance sheet information before 1996, we make a linear prediction for the first two index years. We also tested alternative prediction methods like 'backcasting' regressions including the index value of the next period. Testing for different methods of calculating the index in 1995 and 1996 did not significantly affect our regression results. 
Hypothesis 3 suggests a stronger reaction of large firms to the expiration of DAL. For that reason, we include an additional dummy variable for firms with more than 250 staff members (large) and interact this variable with the before 1999 dummy to estimate a partial differencein-differences estimator for the large firms (DiD large). This results in

$I_{i t}=\beta_{0}+\beta_{1} \cdot \operatorname{DiD}+\beta_{2} \cdot$ large $+\beta_{3} \cdot \operatorname{DiD}$ large $+\gamma \cdot X_{i t}+\alpha_{i}+u_{i t}$,

where $\beta_{1}$ measures the treatment effect for small and medium businesses, $\beta_{3}$ is the difference of treatment effects between large and small businesses, and the sum of $\beta_{1}$ and $\beta_{3}$ captures the treatment effect for large firms. In a similar way we include dummy variables and additional interaction terms in order to test Hypothesis 4 to Hypothesis 6.

\section{Results}

\subsection{Estimation of the DAL effect}

Before we discuss the regression results, we present residual plots as support of our estimation strategy. The residual plots are useful for two reasons. First, they help to illustrate structural changes in data that are not explained by the control variables. This is important, because for the validity of our difference-in-differences approach our results should not be driven by diverging underlying trends in both parts of Germany. Second, residual plots point to yearspecific differences in investment behavior that might provide useful insights.

To construct the residual plots, we estimate regressions based on equation (5), including all control variables but leaving out the interaction term east before99. We estimate four alternative specifications (building investment volume and probability, equipment investment volume and probability). Average residuals for Eastern and Western German establishments are plotted in Figure 3.

[Figure 3 about here]

The residual plots point to higher building investments in the eastern part of Germany until the DAL program expired. After 1998, there is no clear pattern for diverging building investment. That holds in particular if we focus on the average effect over the funding period compared to the average effect over the post-treatment period. We also find low building investment in 1999, not explained by the control variables in the model. This fits well with the argument of House and Shapiro (2008) that investments are shifted in order to receive a 
higher benefit. We obtain similar results for the probability and the volume of building investment.

The residual plots for equipment investment are quite different. For equipment volumes, the residuals for Eastern Germany are positive in 1995 and 1996, but not in 1997 and 1998. An explanation may be found in the more limited impact of bonus depreciation on the net present value of equipment investment. Moreover, in 1997 the German legislator decided to prolong the ISL subsidy program with higher maximum rates (ISL 1999). For equipment investment probability, we find a similar pattern as for building investment, but no sign of an investment pothole in 1999.

Figure 3 does not suggest that differences between residuals are driven by diverging trends in both parts of Germany. Moreover, the residuals of establishments in the western states are fairly stable over time. Therefore, the West can in fact serve as a benchmark for our difference-in-differences estimation.

Table 4a summarizes regression results for investment volumes. The dependent variable is the logarithm of building investment (columns 1 to 4) and equipment investment (columns 5 to 8). The results include 119,659 observations of 31,219 establishments with positive building investment, and 495,594 observations of 63,948 establishments with positive equipment investment. Establishment fixed effects, year fixed effects and - in models (3), (4), (7) and (8) - industry-year fixed effects are included but not reported. The standard errors are heteroscedasticity-robust and clustered on the establishment level.

Due to the logarithmic specification of the dependent variable, our results are to be interpreted as semi-elasticities. Thus, estimated dummy variable coefficients have to be recalculated in order to obtain the relative effect on investment. As shown by Kennedy (1981), the relative change can be approximated by $\exp \left(\hat{\beta}_{i}-1 / 2 \cdot \operatorname{Var}\left(\hat{\beta}_{i}\right)\right)-1$, with the estimated regression coefficient $\hat{\beta}_{i}$ and the variance $\operatorname{Var}\left(\hat{\beta}_{i}\right)$. To capture the average treatment effect for all firms, we initially focus on the models (1) to (3) and (5) to (7). For brevity of exposition we only comment on the fully specified models (3) and (7).

[Table 4a about here]

Confirming Hypothesis 1, the coefficient of DiD is positive and significant in all models on building investment. For equipment investment the effect is weaker and but still significant on the $5 \%$ level if all controls are included (model 7). With respect to the size of the effect, it 
turns out that the average relative increase in building investment (31.3\% in model 3 ) substantially exceeds the corresponding effect on equipment investment (merely $3.1 \%$ in model 7). This confirms Hypothesis 2: Bonus depreciation programs have a stronger impact on building investment than on equipment.

The regression coefficients of the controls are generally in line with our expectations. The variables capital stock and revenue per capital (as measures for size, productivity and cash holdings) are positively related to investments. While share of exports and share of manufacturing are not significant in regressions on building investment, we find a positive and significant coefficient for share of exports in regressions on equipment investment. The unemployment rate is negatively correlated with investment activity, while GDP per capita has a positive sign. While population is not significant, we find a positive and significant effect of forecast error on equipment investment. As expected, overoptimistic expectations in economic growth have, therefore, a positive impact on investment in short-term capital goods. The capital index for eastern as well as western states shows a positive effect on equipment investment and a negative impact on buildings.

Including a difference-in-differences dummy for large firms (DiD large) confirms Hypothesis 3. While the general DAL effect becomes smaller in models (4) and (8), we obtain an additional DAL effect of $57.6 \%$ for building investment and $35.7 \%$ for equipment investment in large firms. In the equipment investment model, the coefficient of $\mathrm{DiD}$ is insignificant, when differentiating between SMEs and large firms. Hence, the average treatment effect of the DAL on equipment is almost exclusively driven by large firms. The total effect of DiD and DiD large suggests $89.8 \%$ higher building investment volume of large firms in the East before 1999. In Table 4b, we explain the decision to invest in buildings or in equipment using a linear probability model. We also estimated logit and probit models with similar results.

[Table 4b about here]

As expected, DiD has a strong impact on the probability of investment in buildings, even in absolute terms. The average $\mathrm{DiD}$ coefficients are quite robust with regard to the model specification and are between 5.1 and 8.9 percentage points for building investment and between 3.3 and 4.1 percentage points for equipment investment. If we relate these effects to the average investment probabilities in our data and focus on models 3 and 7, we find that the probability of investment in buildings increases by $19.6 \%$ compared to merely $3.9 \%$ for equipment investment. The partial DiD estimator for large firms is positive, but only significant for building investment. 
Combining the estimates of Table $4 \mathrm{a}$ and Table $4 \mathrm{~b}$, our results imply that annual building investment in establishments in Eastern Germany between 1995 and 1998 increased on average by $57.0 \%$ - and equipment investment by $7.0 \%$ - due to the DAL. Hence, the change in tax incentives resulting from expiration of the bonus depreciation negatively affected investment. In particular the effects on building investment were remarkable. In addition, large firms with at least 250 staff members showed a much stronger reaction to the incentives.

\subsection{DAL and investment shifting}

To account for possible investment shifting between periods or entities, we include interaction terms for investments in 1997 and 1998 (DiD 1997/98), investments in 1999 (DiD 1999) and investments of firms with more than one establishment (DiD group). As an additional control variable we also consider a group dummy. Table 5a shows the results for investment volumes.

\section{[Table 5a about here]}

The coefficient of $\operatorname{DiD} 1997 / 98$ is negative in all specifications but only significant for equipment investment. This should be driven by two aspects. First of all, DAL bonus depreciation was reduced from 50\% before 1997 to $40 \%$ until it expired at the end of 1998 . Second, while the ISL program was initially intended to run out like DAL, the German legislator in August 1997 decided a prolongation of that program with higher maximum rates. This reduced the incentive to invest in capital goods with short regular depreciation periods in 1997 and 1998. In line with that argument, we find higher equipment investment volumes in 1995-1996 (captured by DiD), ${ }^{7}$ but a negative effect on equipment investment in 1997-98. Our results fit well with the relative tax burden in Eastern Germany in Table 2. While relative tax benefits for building investment are generally higher between 1995 and 1998, this does not hold for all types of equipment investment.

This line of argumentation is further supported by our results for DiD 1999. The coefficient on DiD 1999 is negative and significant in models (1), (3) and (4), implying that building investments have been shifted upfront in order to benefit from the bonus depreciation. However, we obtain positive and significant coefficients in models (5), (7) and (8). Therefore, equipment investments have been delayed to receive higher ISL benefits. This effect could have been driven by misinformation on funding policies. While the initial version of the ISL 1999 proposed higher subsidy rates for the majority of fundable equipment investments, the

7 Note that the inclusion of DiD 1997/98 has an impact on our original DiD estimator. This is not unexpected, as both parameters affect the reference period. If DiD 1997/98 is included, DiD captures exclusively the DAL effect for 1995 and 1996 instead of the whole validity period. 
final version of the law, which was officially decided in December 1999, restricted these higher maximum rates to so-called 'initial investments'. This was due to legal objections of the European Commission regarding European anti-subsidy regulations. Therefore, it might well be the case that shifting equipment investment to 1999 has been suboptimal for some businesses.

Accounting for possible group effects (DiD group), only equipment investment has a positive and significant coefficient. This is in line with the argument that businesses with a large number of establishments benefit more from bonus depreciation policies, as they can shift movable assets between different establishments. However, DiD group is only significant if DiD large is not included. Therefore, this result should be interpreted with caution.

[Table 5b about here]

Table 5b shows our extended regression results for the linear probability model. The estimates generally confirm the regressions on investment volumes. However, DiD 1999 is not significant for the probability of investment in buildings, and the aggregate effect of DiD and DiD 1997/1998 is positive for equipment investment. Furthermore, DiD group is positive and significant for the probability of investment in equipment in all specifications. Hence, there is some evidence that groups with more investment shifting opportunities reacted more strongly to the expiration of the DAL bonus depreciation. In line with Edge and Rudd (2010), that holds exclusively for equipment investment with low adjustment costs. The effect of DiD group on the probability of investment in buildings is not significant.

\subsection{DAL and building prices}

As mentioned earlier, we expect a positive effect of DAL on state-level building prices (Section 3, Hypothesis 7). Price effects on equipment investment have not been looked at, because - given the size of the Eastern German economy - the impact of subsidies on internationally traded movable assets (e.g. machines) should be negligible. First, we look at state-level price indices for new buildings in the manufacturing sector. Table 6 shows weighted average building price indices in Eastern and Western Germany (cf. footnote 5), with 2005 as reference year. It turns out that the building price index is higher in Eastern Germany during the bonus depreciation funding period (1995 to 1998). The difference between the price indices is highest during the first two years with the highest funding level. In later years, the price index is typically higher in Western Germany. Hence, there is some descriptive evidence for a positive impact of DAL on prices for new buildings. 
[Table 6 about here]

To obtain an estimate of the impact of bonus depreciation on building prices in the manufacturing sector, we compute models for building investment volumes adjusted by the general price index for the manufacturing sector instead of state-level building price indices. Results are reported in Table 7. As these regressions do not control for region-specific price effects, the DiD-coefficient can be interpreted as a non-regional-price-adjusted estimate of the DAL effect. Therefore, comparing this result with the regional-price-adjusted estimate of Table 4a allows for an identification of the DAL effect on building prices.

[Table 7 about here]

For the sake of brevity, we only discuss the average DiD estimate including all control variables (model 3). In Table 7, without controlling for regional price variation, we obtain a slightly stronger DiD estimate compared to the model controlling for state-level building prices (36.1\% instead of $31.3 \%$ in Table 4 a). This suggests a relatively small (about 3.7\%) impact of the DAL on building prices in the manufacturing sector.

\subsection{Robustness checks}

Our empirical strategy might be challenged by differences in the characteristics of business establishments in both eastern and western states that are not captured by establishment fixed effects or by our control variables. Therefore, in order to make the treatment and control groups more comparable with each other, we restrict the sample. In the modified sample we only consider business establishments of the three economically strongest federal states of Eastern Germany (treatment group) and the five economically weakest federal states of Western Germany (control group). We use average GDP per capita and the average unemployment rate on state level as two alternative criteria for the selection of states in Eastern and Western Germany. Hence, we select states with the lowest/highest GDP per capita and states with the highest/lowest unemployment rate in Western/Eastern Germany. The selection is based on indicators in 1990 to avoid an impact of bonus depreciation policies on the selection criteria. Note that the relative economic strength of states in Eastern and Western Germany is remarkably stable over time. These robustness checks generally confirm our basic regression results (Table A.1).

Furthermore, it might be argued that investments in the respective parts of Germany are not independent. In that case firms with establishments in both parts of Germany would predictably be more strongly affected by the DAL program, as investments might have been 
shifted to their establishments in the East. To account for this, we ran regressions for firms with establishments in both parts of Germany (mixed firms) and for a sample excluding mixed firms. We did not find evidence for a stronger reaction of mixed firms and the exclusion of mixed firms has only a minor effect on our estimates (Table A.2).

In addition, we ran robustness checks that are not reported in the paper. ${ }^{8}$ To meet the argument that the control variables measuring regional economic development and firm characteristics could be endogenous, we included lagged control variables. There is no evidence that either lagged regional or lagged establishment controls, or lagged establishment and regional controls together have any significant impact on the outcome. So, as including lags results in the loss of the 1995 observations, which is an important year for our study, we decided to stick to our baseline specification.

Since it might be argued that revenue per capital stock is not sufficient to control for capital constraints (for capital constraints and investment see Hadlock and Pierce, 2010), we also tested models including EBITDA per capital (as a measure of cash flow), interest per capital (as a measure of debt ratios) and the legal form (as a measure of financing opportunities). As this information is not available for all observations, the sample size was reduced by about $50 \%$. Within these models, the inclusion of additional controls did not significantly affect our outcome.

Our regressions are based on the logarithm of investment and not on investment scaled by capital stock. The main advantage of this approach is that our dependent variable is not affected by potential measurement error of capital stock (Zwick and Mahon, 2014). In addition, a logarithmic specification allows us to interpret the regression coefficients as (semi)-elasticities. Nevertheless, we conducted regressions on scaled investment as cross checks. While the overall fit of these models is smaller $\left(\mathrm{R}^{2}\right.$ is generally below $\left.5 \%\right)$, we still find a significant and positive impact of $\mathrm{DiD}$ on equipment and especially building investment.

In our regressions, we define investment as gross investments on the establishment level, which can be directly depreciated by the firm. Thus, our regressions do not account for leasing of long-term capital goods. Therefore, we also estimated cross checks accounting for gross investments and leased capital goods. Results are almost identical to our original regression specification.

8 Results can be provided by the authors upon request. 
Finally, we calculated regressions for subgroups of the manufacturing industry considering (a) low-tech industries like the production of food, textiles, leatherware, woodware, or paperware, (b) establishments producing chemicals and materials (e.g. oil products, pharmaceuticals, synthetic materials, metals and metal products), and (c) high-tech industries like car production, engineering, and computer production. Again, the results of these modifications were robust.

\section{Conclusion}

Addressing the question in our paper whether and to what extent bonus depreciation might affect business investment, we interpret a change of tax incentives for manufacturing businesses in Eastern Germany as a natural experiment. When the bonus depreciation program (the Development Area Law DAL) ran out in 1998, tax incentives changed, with the focus shifted towards SMEs and investment in machinery and facilities. As policy variation over time has affected the two German regions - the western and eastern states - differently, we use a difference-in-differences approach as our identification strategy.

Confirming theoretical considerations, we find evidence for a significant and strong impact of bonus depreciation on investment. This holds in particular for investment in long-lived capital goods like non-residential real estate and structures. Our evidence implies that building investment before 1998 was higher by $57.0 \%$ - and equipment investment by $7.0 \%$ - due to the change in funding policies. The stronger impact on building investment was arguably driven on the one hand by the higher value of bonus depreciation for assets with long depreciation periods, and on the other by the announcement in August 1997 of higher maximum ISL benefits after 1998.

In contrast to Zwick and Mahon (2014), we find a much stronger effect of DAL on large firms. While the average increase of equipment investment volume in the DAL period is insignificant for SMEs (although their building investment volume was higher by 20.4\%), we obtain an estimate of $35.7 \%$ for large firms (and 89.8\% for their building investment). As there are no major differences in the subsidy level for building investments of large firms and SMEs, our results support the conjecture that large firms generally react more strongly to bonus depreciation policies. This is in line with Knittel (2007), who finds low take-up rates of the 2002 U.S. bonus depreciation for small businesses. A convincing explanation for that outcome is tax complexity associated with economies of scale in tax planning. One may 
conclude that complex tax incentive programs tend to be more profitable for large firms and less salient for small firms (for general evidence on tax salience see Chetty, 2009).

Our research suggests a shifting of investment between periods in order to receive the highest benefit. For equipment investment, we find higher investment levels in 1995 and 1996 compared to 1997 and 1998. This can be explained by a reduction of maximum bonus depreciation rates (from $50 \%$ to $40 \%$ ) and by the announcement of a prolongation of the ISL direct subsidies with increased maximum rates in August 1997. Thus, in spite of a limitation of these higher ISL maximum rates to 'initial equipment investment' as decided by December 1999, there was an ex ante incentive to postpone equipment investment into the year 1999. In line with this argument, we find an increase in average equipment investment in 1999. Note that the legal disputes between the European Communities and the German government on European anti-subsidy regulations in 1999 might have resulted in (ex post) suboptimal investment decisions on the firm level.

Building investment in 1999, however, was low compared to the preceding and following periods. This is in line with theoretical considerations of an investment pothole in the period after the expiration of a tax incentive program (House and Shapiro, 2008; Edge and Rudd, 2010), because bonus depreciation is most valuable for capital goods with long regular depreciation periods. We also find some evidence that corporate groups with a number of establishments reacted more strongly to the change in funding policies in the case of equipment investment. This is in line with higher investment shifting opportunities and lower planning costs for corporate groups in the case of movable assets with low investment adjustment costs.

While the literature hypothesized a positive effect of bonus depreciation and other forms of investment tax incentives on asset prices, the existing empirical evidence is not conclusive (House and Shapiro, 2008; Edgerton, 2011). In our data, we find some evidence that DAL resulted in higher prices for new buildings in Eastern Germany. However, our analysis suggests only a small effect of DAL on immovable assets like buildings. While average building investment volumes (including the price effect) increased by $36.1 \%$, our estimate for the price effect as such is only $3.7 \%$.

Our analysis is restricted in a number of ways. Despite the exogenous policy variation and the comprehensive data base, establishments in Eastern and Western Germany cannot be regarded as random samples. We included a comprehensive set of control variables and a number of robustness checks to account for that aspect. Moreover, due to ISL benefits in 1999 and later 
years, our standard DiD estimates are not exclusively driven by the DAL bonus depreciation, but rather by a mix of funding policies. We account for this phenomenon in deriving our hypotheses and in interpreting our results.

Regarding fiscal policy, our paper has a number of important implications. First of all, bonus depreciation seems to be an effective instrument of countercyclical or regional fiscal policy if regular depreciation periods are long. Hence, the subsidy is very effective in promoting longterm investment in production sites, administrative buildings and other structures with only a limited effect on corresponding asset prices. Nevertheless, we also find a significant impact of bonus depreciation on equipment investment in spite of higher ISL maximum funding rates in 1999 and thereafter. Secondly, the complexity of subsidy programs seems to restrain the response of small businesses compared to large firms (Knittel, 2007), which has clear policy implications. Restricting programs to small firms might reduce their overall effectiveness. Extending incentive programs to large firms increases the effectiveness (take-up rates), but also affects competition between large and small firms in favor of the large. An implication of this might be to aim for simple, and therefore cost-effective, incentive programs. Thirdly, we find evidence for shifting investments between periods in order to receive higher benefits. This suggests that the long-term effects of temporary incentive programs on the capital stock in a given period should be smaller than short-term effects on investment.

We finally note that our analysis has been positive and not normative. Thus, while the subsidy was effective in promoting business investments in the manufacturing industry of Eastern Germany, it cannot be ruled out that the investment induced by tax benefits may have been inefficient. Bonus depreciation may be well-suited to accelerate economic recovery in the short run, but it still remains an open question whether investment incentives are welfareenhancing in the long run. 


\section{Appendices}

\section{Appendix A: Present value of DAL benefits}

\section{A.1. Calculation of DAL present value}

The benefit of DAL is the tax allowance resulting from the sum of the bonus depreciation during the first year and the present value of regular depreciations in the future, instead of using the alternative depreciation scheme without the bonus depreciation. The present value

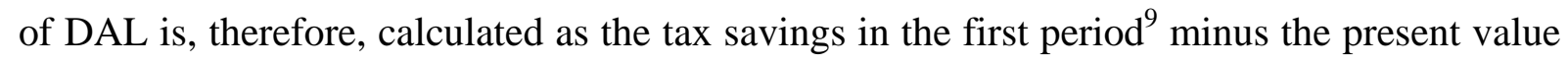
of alternative depreciation schemes. The DAL benefit is calculated from the perspective of a given period $t$, so we do not account for changes in taxes and the after-tax cost of funds in future periods. Taking into account that German tax rates declined after 1998, we calculate a lower-bound estimate of the ex-post DAL benefit, because the value of depreciation benefits increases with the tax rate. Thus, decreasing tax rates imply a lower value of future depreciations. Furthermore, we do not account for the possibility of future tax losses that would reduce the present value of future tax depreciation. ${ }^{10}$ The DAL bonus depreciation is fully utilized in the first year and the investment is executed in the middle of the year. The present value of DAL benefits is then equal to

$$
P V_{t}=\tau_{t} \cdot \Phi_{t} \cdot\left(\beta_{t}+\left(1-\beta_{t}\right) \cdot \sum_{t+p}^{P} \frac{\text { sreg }_{t p}}{\left(1+c_{t \tau}\right)^{p-1}}-\sum_{t+p}^{P} \frac{\delta a l t_{t p}}{\left(1+c_{t \tau}\right)^{p-1}}\right)
$$

where $\Phi_{t}$ denotes the total sum of depreciations in a given year $t, \tau_{t}$ the average tax rate in $t$, $c_{t \tau}$ the after-tax cost of funds and $p$ an index for following periods. The bonus depreciation rate of a given period (ranging from $40 \%$ to $50 \%$ ) is denoted by $\beta_{t}$. Thus, $\left(1-\beta_{t}\right)$ is the remaining book value to be depreciated by the regular scheme. The parameters $0 \leq \delta r e g_{t p} \leq 1$ and $\left(0 \leq \delta a l t_{t p} \leq 1\right)$ describe the allocation of depreciations under the regular scheme and the alternative scheme respectively.

Advance tax payments in Germany are affected by depreciation allowances. Therefore, in line with Cohen, Hansen, and Hassett (2002), we reduce the number of discounting periods $p$ by one. It should be noted that the subsidy reports of the German government do not report the

9 These are documented in the subsidy reports of the German government; see Deutscher Bundestag, Drucksache 12/1525, Drucksache 13/2230, Drucksache 14/1500, Drucksache 15/1635, Drucksache 16/6275.

10 In case of a tax loss, the remaining depreciation volume does not result in a reduction of the tax burden (the tax payment is zero anyway), but increases the loss carryforward. Thus, future losses might decrease the present value of the remaining depreciation volume. 
total amount of depreciations $\Phi_{t}$, but only the amount of losses resulting from bonus depreciation $\tau_{t} \cdot \Phi_{t} \cdot \beta_{t}$. Thus, we use this information to calculate $\tau_{t} \cdot \Phi_{t}$. Concluding, (A.1) describes the advantage of the bonus depreciation, increased by the present value of the remaining regular depreciation scheme and reduced by the present value of the alternative depreciation scheme.

\section{A.2. After-tax cost of funds}

An important aspect affecting the present value of depreciation allowances is the after tax-cost of funds. Using the definition of weighted average costs of capital (WACC) (see Hulse and Livingstone, 2010; Frank and Shen, 2012), after-tax costs of funds in $t$ can be written as

$$
c_{\tau t}=c_{t d} \cdot d \cdot\left(1-\tau_{t^{*}}\right)+c_{t e} \cdot(1-d)
$$

In (A.2), $c_{t d}$ denotes the pre-tax cost of debt capital in time $t, c_{t e}$ the cost of equity capital, and $d$ the - for simplicity constant - fraction of debt capital. The tax-deductibility of interest payments on the firm level is considered by the tax rate $\tau_{t^{*}}$ accounting for the limited taxdeductibility of interests for long-term debt with regard to the German local business tax (German: Gewerbesteuer).

To approximate the cost of debt capital $c_{t d}$ for a given year $t$, we use average long-term interest rates published by the German Federal Bank (German: Deutsche Bundesbank). ${ }^{11}$ This can be justified by the fact that investments are generally financed by equity and long-term debt, while short-term debt is more relevant for operational business. The average interest rate between 1995 and 2008 was 6.07\%. The average fraction of debt capital is taken from representative balance sheet statistics of the manufacturing industry, which are also provided by the German Federal Bank (2012). In line with Hulse and Livingstone (2010), we focus on the fraction of long-term debt and equity. Therefore, we assume that short-term debt and accruals result from operational business and do not affect the after-tax cost of funds of longterm business investment. We do not observe strong changes in $d$ during our sample period.

11 Since the definitions of reported interest rates of the German Federal Bank change over time, we rely on a number of different proxies for the cost of debt capital. For 1997 to 2002 we use average interest rates for business credits ranging from $€ 500,000$ to $€ 5 m$ (BBK01.SU0509). For 2003 and thereafter, we use interest rates for credits to corporations exceeding $€ 1 \mathrm{~m}$ and a duration of more than 5 years (BBK01.SUD129). For the period from 1991 to 1996, we use floating long term mortgage interest rates (BBK01.SU0049) as business interest rates are not available. We use 'overlapping' periods with more than one possible proxy of interest rates to adjust all interest rates to a consistent definition over the whole period, using interest rates from 1997 to 2002 as our reference point (BBK01.SU0509). 
Therefore, we rely on a fixed average value of $d=0.3439$, which is close to the usually assumed debt finance ratio of 30\% (Frank and Shen, 2012).

In contrast to the cost of long-term debt, the cost of equity capital is not published by the German Federal Bank. In addition, in spite of a considerable number of possible proxies for $c_{t e}$, there is no generally accepted definition of this variable. Botosan, Plumlee, and Wen (2011) describe 10 alternative proxies with a positive and significant correlation with future realized returns; we rely on the mean of these 10 proxies for equity cost as reported by Botosan, Plumlee, and Wen (2011). It should be noted that the values of $c_{t e}$ are based on U.S. data instead of German data. However, this should not be a severe problem, as Hail and Leuz (2006) do not find evidence for strong differences in the equity cost of capital in the two countries. Nevertheless, we reweight equity cost by corresponding differences reported by Hail and Leuz (2006) and obtain an average cost of 11.0\%. To obtain average values per year, we relate this value with the average cost of long-term debt and obtain a multiplier of 1.814 . Thus, average $c_{t e}$ can be defined as $c_{d t} \cdot 1.814$. This is very close to the relationship between $c_{t d}$ and $c_{t e}$ of 1.8 as assumed by Hulse and Livingstone (2010).

The tax rate $\tau_{* t}$ is a weighted effective tax rate for retained earnings of businesses in Eastern Germany. To calculate $\tau_{t^{*}}$, we account for the distribution between profits generated by corporations (taxed at corporate income tax rates) and by self-employed businesses and partnerships (taxed at personal income tax rates). The fraction of profits generated by corporations is approximated by the corresponding distribution of revenue as documented in the VAT statistics of the German Federal Statistical Office. To calculate the effective tax rate of corporations (partnerships), we use the corporate income tax rate (the maximum marginal personal income tax rate) for accumulated business profits of a given year. We further consider the solidarity tax surcharge (German: Solidaritätszuschlag) and the average local business tax rate (German: Gewerbesteuer) of the eastern German states. We account for the fact that local business tax payments have been deductible from taxable income until 2007. In addition, we account for the local business tax credit for partnerships (German: Gewerbesteueranrechnung) and the add-backs of long-term debt for the German local business tax (German: Hinzurechnungen). The upper-bound deduction for interest income, which has been in place since 2008 (German: Zinsschranke), is not considered. 


\section{A.3. Depreciation regulations}

To calculate the parameters $0 \leq \delta r e g_{t p} \leq 1$ and $0 \leq \delta a l t_{t p} \leq 1$ in (A.1) we rely on the depreciation regulations of the German income tax code for different asset classes, as well as for the distribution of real investments between buildings and equipment for a given year (see German Federal Statistical Office, 2010, Tables 2.1, 3.1 and 4.1).

In the 1990s new buildings were generally depreciated over a period of 25 years. For investments after 2000, these depreciation periods for new business buildings were increased to 33.3 years. For the modernization (extension, improvement) of old buildings, longer depreciation periods of 40 and 50 years (depending on the construction date of the building) were in force. We use the average fraction of new buildings as reported in the German building statistics of the corresponding period ${ }^{12}$ to construct weights for old and new buildings. For modernizations, we assume that one half of investments is depreciated over 40 and the other half over 50 years.

Furthermore, we account for declining depreciation schemes for new buildings and modernizations as documented in $\S 7$ section 5 of the German income tax code. These alternative depreciation schemes were available if (1) the new building was constructed, or old building modernized, with a building application before January 1994 or January 1995 respectively; or (2) the building was purchased before January 1994 or January 1995 respectively. As buildings are typically constructed after the building application has been receive, we assume that declining depreciation schemes are available for two years after the expiration date (100\% in the first year after the abolition and 50\% in the second year).

There is no data on average tax depreciation periods for equipment investment in Germany. Therefore, we assume an average depreciation period of seven years as documented by Devereux et al. (2009). In the 1990s, the general declining depreciation rate for movable assets was $30 \%$. Hence, we assume that all equipment investments use declining depreciation schemes, as long as they are 'higher' than the alternative linear depreciation scheme. Note that declining depreciation schemes were not available if the bonus depreciation was utilized. Therefore, the consideration of these programs reduces to some extent the relative advantage of bonus depreciation.

12 We rely on the number of constructed non-residential buildings in Eastern Germany (new buildings versus modernizations during the period from 1993 to 1999, which was relevant for the Development Area Law). 


\section{Appendix B: Calculation of the relative tax incentive}

As denoted by (4), the relative tax burden of investments in Eastern Germany can be written as

$R T_{t}=\frac{1-\tau_{t}^{E} \cdot Z_{t}^{E}-z_{t}^{E}}{1-\tau_{t}^{W} \cdot Z_{t}^{W}-z_{t}^{W}} \cdot \frac{1-\tau_{t}^{W}}{1-\tau_{t}^{E}}$,

where $\tau_{t}^{E}, Z_{t}^{E}$ and $z_{t}^{E}\left(\tau_{t}^{W}, Z_{t}^{W}, z_{t}^{W}\right)$ denote the tax rate on profits, the present value of depreciations per $€$ invested and the effective ISL subsidy rate for Eastern Germany in a given period. As in Appendix A, $\tau_{t}^{E}$ and $\tau_{t}^{W}$ are based on weighted tax rates of partnerships and corporations including taxes on income, the solidarity tax surcharge and the local business tax. To calculate $\tau_{t}^{E}\left(\tau_{t}^{W}\right)$, we use average local business tax multipliers (German: Hebesätze) for Eastern and Western Germany. $Z_{t}^{E}$ and $Z_{t}^{W}$ are calculated as in Appendix A. The after-tax costs of funds of A.2 are used to compute discounted values of depreciation allowances.

We account for the fact that applications for ISL subsidies are generally related to investments of the preceding year. Therefore, the effective subsidy rate $z_{t}^{E}$ is defined as the nominal ISL rate discounted by one period. Corresponding to Table 1, the ISL rate for equipment investment and large firms is 5\% (small firms 10\%) from 1995 to 1998, 10\% (small firms $20 \%$ ) in 1999, and $12.5 \%$ (small firms 25\%) thereafter. Regarding building investment, funding rates were zero before 1999 and there were no higher rates for small and medium businesses. There was also a higher subsidy rate of $8 \%$ for equipment investment of all firms before 1997 if investments had been initiated before June 1994. We assume that this is relevant for 50\% of investments in 1995 and 0\% thereafter. Correspondingly, we assume that the increase of funding rates in 2000 (from $10.0 \%$ to $12.5 \%$ ) was relevant for $50 \%$ of businesses in that period and $100 \%$ thereafter. It should be noted that $z_{t}^{W}$ is generally zero, as ISL subsidies were restricted to investments in the East. In addition, there was a funding gap for investments initiated before August 25, 1997 and completed after December 31, 1998. For simplicity, we do not consider this aspect in our calculations. This may be justified by the fact that this ‘funding gap’ was not known to business owners and managers.

\section{Appendix C: Calculation of capital stock}

Our calculation is based on an approach developed by Wagner (2010), who uses depreciation values for tax purposes reported in the Cost Structure Survey, information on the composition 
of investments from the Investment Survey and average depreciation periods for different asset classes (buildings and equipment) to compute capital stocks. Our method extends the approach of Wagner in a number of ways and can be described by

$$
K_{i, t-1}=\left(D_{i t} \cdot\left(\alpha_{i t}{ }^{E} \cdot P_{t}^{E}+\alpha_{i t}^{B} \cdot P_{t}^{B}\right)-I_{i t}^{N}\right) \cdot 1 / 2,
$$

where $K_{i, t-1}$ is the capital stock at the end of the previous period (or beginning of the current period) of the firm $i, D_{i t}$ is the depreciation of $i$ in $t, \alpha_{i t}{ }^{E}$ is the fraction of equipment investment of a given year, $\alpha_{i t}{ }^{B}$ the fraction of building investment in that year, and $P_{t}^{E}\left(P_{t}^{B}\right)$ the average depreciation period for equipment (building) investment in Germany in $t$.

Multiplying the sum of depreciations with the average depreciation period yields the investment value at the beginning of the operating period. To account for depreciations after the beginning of the operating period of an asset, we divide this value by two. Therefore, we assume that the average operating period has expired by a factor of $50 \%$ for each asset. This implies further that price-adjusted depreciations are approximately evenly distributed over time. Note that investments in $t$ have a positive effect on $D_{i t}$. If investments are executed in the middle of the year, $D_{i t}$ should rather be a measure of the capital stock in the middle of the period instead of the beginning of the period. To account for that aspect, we deduct $50 \%$ of net investments $I_{i t}^{N}$ (defined as gross investment minus disinvestment) of firm $i$ in time $t$.

The depreciation period $P_{t}^{E}$ for equipment is assumed to be 7 years (see Appendix A as well as Devereux et al., 2009). For new buildings, the regular rates are 25 years (for old buildings 40 to 50) years. For simplicity, we do not account for declining depreciation schemes. This can be justified by the fact that declining schemes increase the present values of depreciation allowances, but not the average depreciation over the depreciation period. The composition of different asset classes is measured by the distribution of investments $\alpha_{i t}{ }^{E}$ and $\alpha_{i t}{ }^{B}$ with $\alpha_{i t}{ }^{E}+\alpha_{i t}{ }^{B}=1$. To account for measurement error, we calculate average values for $\alpha_{i t}{ }^{E}$ and $\alpha_{i t}{ }^{B}$ by year, industry, business size (large firms compared to small firms with up to 250 staff members) and region (Eastern versus Western Germany).

The tax depreciation period for new buildings increased to 33.3 years in 2001, while depreciation periods for modernizations remained unchanged. The increased depreciation period is only relevant for new installments. Thus, considering economic growth and 
declining depreciation schemes of preceding periods, we assume a declining adaptation process of the average depreciation period per firm over 25 years with $D_{2000+x}=D_{2000}+\Delta \cdot \sqrt{\frac{x}{25}}$, where $D_{2000}$ denotes the average depreciation period in 2000 (29 years on average for old and new buildings), $\mathrm{x}$ the number of years after 2000 and $\Delta$ the increase in the average depreciation period resulting from the reform. This yields an average depreciation period for buildings of 35.66 years in 2008 .

The computation of the capital stock may be affected by measurement error in $D_{t}$. This is especially a problem in the case of a high variation of tax depreciations over time, implying a fluctuating capital stock. To take account of that aspect, we rely on estimated capital stocks of future periods to obtain a more consistent estimate of the capital stock of preceding periods. We use this 'count-back' method, because the first years of our data base are more relevant for the investigation of DAL benefits. Hence, we define the capital stock of the preceding period as the capital stock of the following period plus investments and minus depreciations and disinvestments in $t$.

In addition to fixed assets, and extending the approach of Wagner (2010), we consider leased investments as increasing the effective capital-in-kind. We rely on data from the Investment Survey to compute the ratio of leased assets to fixed assets by year, industry, business size and region (Western versus Eastern Germany). The value of fixed assets of each firm is multiplied by one plus the computed ratio.

One drawback of our data is that depreciation volumes of the Cost Structure Survey are only available on the firm level, while our research is focused on establishment data. Therefore, we allocate depreciations to the establishment. We compute the ratio of the capital stock to the number of staff members by year, industry, business size (large firms compared to small firms with up to 250 staff members) and region (establishments in the West and establishments in the East). Using these ratios, we allocate the firms' capital stock to the establishments.

\section{Appendix D: Robustness checks}

Table A.1 documents our regression results for the adjusted treatment and control groups. To make treatment and control group more comparable to each other, we only consider establishments in the five economically weakest western states and the three economically strongest eastern states (excluding Berlin). Selection is based on unemployment rates (model 
1 to 4 ) or GDP per capita ratios (model 5 to 8 ) in 1995. For the alternative treatment and control groups, the results are in line with our baseline specification.

[Table A.1 about here]

Table A.2 summarizes the regression results for firms with at least one establishment in both parts of Germany as well as for a sample of firms excluding these observations. It turns out that the exclusion of firms with establishments in both parts of Germany does not affect our estimates on $\mathrm{DiD}$ and $\mathrm{DiD}$ large. In addition, we do not find that establishments of firms that are active in both parts of Germany are more strongly affected by DAL. This can be taken as evidence that our regression results are not biased due to interdependencies between both parts of Germany. If interdependencies have a strong impact on investment decisions, we would expect a stronger reaction of firms with establishments in both parts of the country.

[Table A.2 about here]

\section{Acknowledgements}

We are grateful for comments and advice to Johannes Becker, Kay Blaufus, Timm Bönke, Thiess Buettner, Estelle Dauchy, Nadine Fabritz, Shane Heitzmann, Jochen Hundsdoerfer, Martin Jacob, Aloys Prinz, Craig Sisneros, Joe Swann, Andreas Wagener, Matthias Wrede, the participants of the research colloquium 2012 at the University of Duisburg-Essen, the research colloquium 2012 of the University of Düsseldorf, the arqus Conference 2012 in Tübingen, the IIPF Annual Meeting 2012 in Dresden, the Verein für Socialpolitik Annual Meeting 2012 in Göttingen, the public finance research colloquium at the University of Münster 2013, the research seminar of the University of Erlangen-Nürnberg 2013, the VHB Annual Conference 2013 in Würzburg, the EIASM Workshop on Current Research in Taxation 2013 in Münster and the AAA Annual Meeting 2013 in Anaheim, CA. Furthermore, we are grateful to two anonymous referees for the VHB Annual Meeting 2013 and one anonymous referee of the AAA Annual Meeting 2013. We thank the Research Data Centers of the German Federal and State Statistical Offices for the provision of data. For technical support and advice we are grateful to Anja Hlawatsch, Julia Höninger, Matthias Klumpe, Katrin Kornführer, Ulrich Krumbein, Michael Roessner and Andreas Schwill. All remaining weaknesses are our own.

\section{References}

Auerbach, A.J., Summers, L.H., 1979. The investment tax credit: An evaluation. NBER Working Paper 404. NBER, Cambridge/MA.

Auerbach, A.A., 1983. Taxation, corporate financial policy and the cost of capital. Journal of Economic Literature 21 (23), 905-940.

Auerbach, A.A., Hassett, K. 1992. Tax policy and business fixed investment in the United States. Journal of Public Economics 47 (19), 141-170.

Becker, Bo, Jacob, M., Jacob, M. 2013. Payout taxes and the allocation of investment. Journal of Financial Economics 107 (1), 1-24. 
Billings, B.A., Musazi, B., Houston, M., 2008. Bonus depreciation tax incentives may not work for needy firms. Tax Notes 118, 735-737.

Botosan, C.A., Plumlee, M.A., Wen, H., 2011.The relation between expected returns, realized returns, and firm risk characteristics. Contemporary Accounting Research 28 (4), 1085-1122.

Chetty, R., 2009. Salience and taxation: Theory and evidence. American Economic Review 99 (4), 1145-1177.

Chirinko, R.S., Fazzari, S.M., Meyer, A.P., 1999. How responsive is business capital formation to its user cost? An exploration with micro data. Journal of Public Economics 74 (1), 53-80.

Chirinko, R.S., Wilson, D.J., 2008. State investment tax incentives: A zero-sum game? Journal of Public Economics 92 (12), 2362-2384.

Cohen, D., Cummins, J.G., 2006. A retrospective evaluation of the effects of temporary partial expensing, Finance and Economics Discussion Paper 2006-19, Federal Reserve Board, Washington D.C.

Cohen, D., Hansen, D.P., Hassett, K.A., 2002. The effects of temporary partial expensing on investment incentives in the United States. National Tax Journal 55 (3), 457-466.

Cummins, J.G., Hassett, K.A., Hubbard, R.G., 1996. Tax reforms and investment: A cross-country comparison. Journal of Public Economics 62 (1-2), 237-273.

Dauchy, E., Martinez, C., 2008. Corporate tax minimization and the effectiveness of investment tax incentives. NTA Proceedings of the $100^{\text {th }}$ Conference on Taxation, 267-277.

Desai, M.A., Goolsbee, A.D., 2004. Investment, overhang and tax policy. Brookings Papers on Economic Activity 2004 (2), 285-338.

De Long, J.B., Summers, L.H., 1991. Equipment investment and economic growth. The Quarterly Journal of Economics 106 (2), 445-502.

Devereux, M.P., Keen, M., Schiantarelli, F., 1994. Corporation tax asymmetries and investment: Evidence from U.K. panel data. Journal of Public Economics 53 (3), 395-418.

Devereux, M.P., Elschner, C., Endres, D., Spengel, C., 2009. Effective tax levels using the Devereux/Griffith method, Project for the EU Commission TAXUD/2008/CC/09, ZEW, Mannheim/Oxford.

Edge, R.M., Rudd, J.B., 2010. General equilibrium effects of investment tax incentives. Finance and Economics Discussion Paper 2010-17, Federal Reserve Board, Washington D.C.

Edgerton, J., 2010. Investment incentives and corporate tax asymmetries. Journal of Public Economics 94 (1112), 936-952.

Edgerton, J., 2011. The effects of taxation on business investment: New evidence from used equipment. Working Paper, Federal Reserve Board, Washington D.C.

Edgerton, J., 2012. Investment, accounting, and the salience of the corporate income tax. NBER Working Paper 18472, NBER, Cambridge/MA.

Eichfelder, S., Schorn, M., 2012. Tax compliance costs: A business administration perspective. FinanzArchiv 68 (2), 191-230.

Feld, L.P., Heckemeyer, J.H. 2011. FDI and taxation: A meta-study. Journal of Economic Surveys 25 (2), $233-$ 272.

Frank, M.Z., Shen, T., 2012. Investment, Q and weighted average costs of capital, Paper presented at the Northern Finance Association 2012, http://northernfinance.org/2012/program/papers/57.pdf.

German Council of Economic Experts, 2011. Verantwortung für Europa wahrnehmen: Jahresgutachten 2011/12 [Taking responsibility for Europe: Annual report 2011/12], URL: www.sachverstaendigenratwirtschaft.de/fileadmin/dateiablage/download/gutachten/ga11_ges.pdf.

German Federal Bank, 2012. Verhältniskennzahlen aus Jahresabschlüssen deutscher Unternehmen von 1996 bis 2008 - Statistische Sonderveröffentlichung 6 [Proportional indicators from annual accounts of German firms in 1996 to 2008 - Statistical special publication 6], URL: http://www.bundesbank.de/Navigation/DE/Statistiken/Unternehmen_und_private_Haushalte/ Unternehmensabschluesse/Tabellen/tabellen.html.

German Federal Statistical Office, 2010. Bruttoanlageinvestitionen in den Ländern und Ost-WestGroßraumregionen Deutschlands 1991 bis 2008 Reihe 1, Band 3 [Gross Investment in the Federal States in Eastern and Western Germany 1991-2008.], URL: www.statistikportal.de/StatistikPortal/publ.asp\#Gesamtrechnungen. 
Gunz, S., MacNaughton, A., Wensley, K., 1995. Measuring the compliance cost of tax expenditures: The case of research and development incentives. Canadian Tax Journal 43 (6), 2008-2034.

Hadlock, C.J., Pierce, J.R., 2010. New evidence on measuring financial constraints: moving beyond the kz index. Review of Financial Studies 23 (5), 1909-1940.

Hail, L., Leuz, C., 2006. International differences in the cost of capital: Do legal institutions and securities regulation matter? Journal of Accounting Research 44 (3), 485-531.

Hall, R.E., Jorgenson, D.W., 1967. Tax policy and investment behavior. American Economic Review 57 (3), 391-414.

Hayashi, F., 1982. Tobin's marginal q and average q: A neoclassical interpretation. Econometrica 50 (1), $213-$ 224.

House, C.L., Shapiro, M.D., 2008. Temporary investment tax incentives: Theory with evidence from bonus depreciation. American Economic Review 98 (3), 737-768.

Hulse, D.S., Livingstone, J.R., 2010. Incentive effects of bonus depreciation. Journal of Accounting and Public Policy 29 (6), 578-603.

Judd, K.L., 1985. Short-run analysis of fiscal policies in a simple perfect foresight model. Journal of Political Economy 93 (2), 298-319.

Judd, K.L., 1999. Optimal taxation and spending in general competitive growth models. Journal of Public Economics 71 (1), 1-26.

Kennedy, P., 1981. Estimation with correctly interpreted dummy variables in semi-logarithmic equations. American Economic Review 71 (4), 801.

Key, K.G., 2008. Taxes and asset prices: the case of thoroughbreds. Journal of the American Taxation Association 30 (1), 29-48.

Knittel, M., 2007. Corporate response to accelerated tax deprecation: Bonus deprecations to tax years 2002 to 2004. OTA Working Paper 98, U.S. Department of the Treasury, Washington D.C.

Malchin, A., Voshage, R., 2009. European data watch: Official firm data for Germany. Schmollers Jahrbuch/Journal of Applied Social Sciences 129 (3), 501-513.

Park, J., 2012. The role of leasing in the effectiveness of corporate tax policy: Evidence from the 2002 bonus depreciation. Working Paper, University of Michigan.

Rego, S., 2003. Tax avoidance activities of U.S. multinational corporations. Contemporary Accounting Research 20 (4), 805-833.

Richardson, G., Lanis, R. (2007): Determinants of the variability in corporate effective tax rates and tax reform: Evidence from Australia. Journal of Accounting and Public Policy 26 (6), 689-704

Sinn, G., Sinn, H.-W., 1993. Jumpstart - The economic unification of Germany. The MIT Press, Cambridge MA/London.

Wagner, J. (2010) Estimated capital stock values of German manufacturing enterprises covered by the structure cost surveys. Schmollers Jahrbuch/Journal of Applied Social Sciences 130 (3), 403-408.

Wielhouwer, J., Wiersma, E., 2013. Arbitrary tax depreciation to stimulate investment: Utilization and effects. Paper presented at the $3^{\text {rd }}$ Workshop on Current Research in Taxation at the University of Münster.

Zwick, E., Mahon, J., 2014. Do financial frictions amplify fiscal policy? Evidence from business investment stimulus. Working Paper, Harvard University. 


\section{Figures and tables}

Figure 1: Subsidy volumes of the DAL and ISL

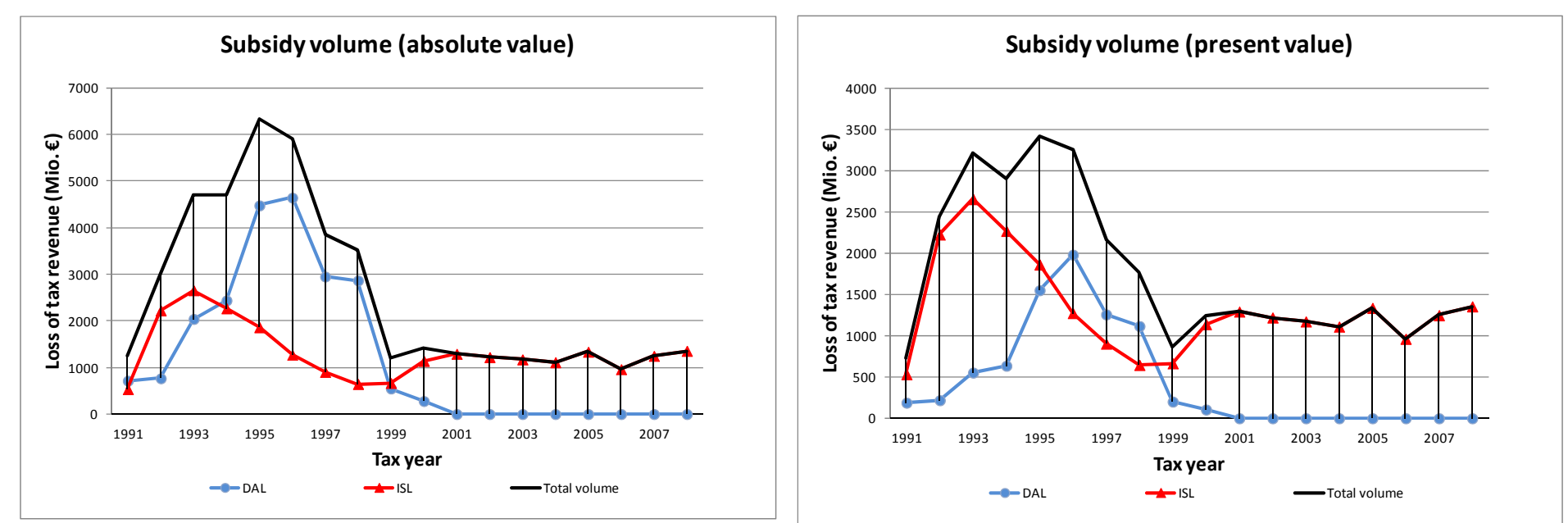

Note: Based on the German government reports on subsidies (see Deutscher Bundestag, Drucksache 12/1525, Drucksache 13/2230,

Drucksache 14/1500, Drucksache 15/1635, Drucksache 16/6275) and own calculations (see Appendix A). 
Figure 2: Investment activity (manufacturing industry, 2000=100)

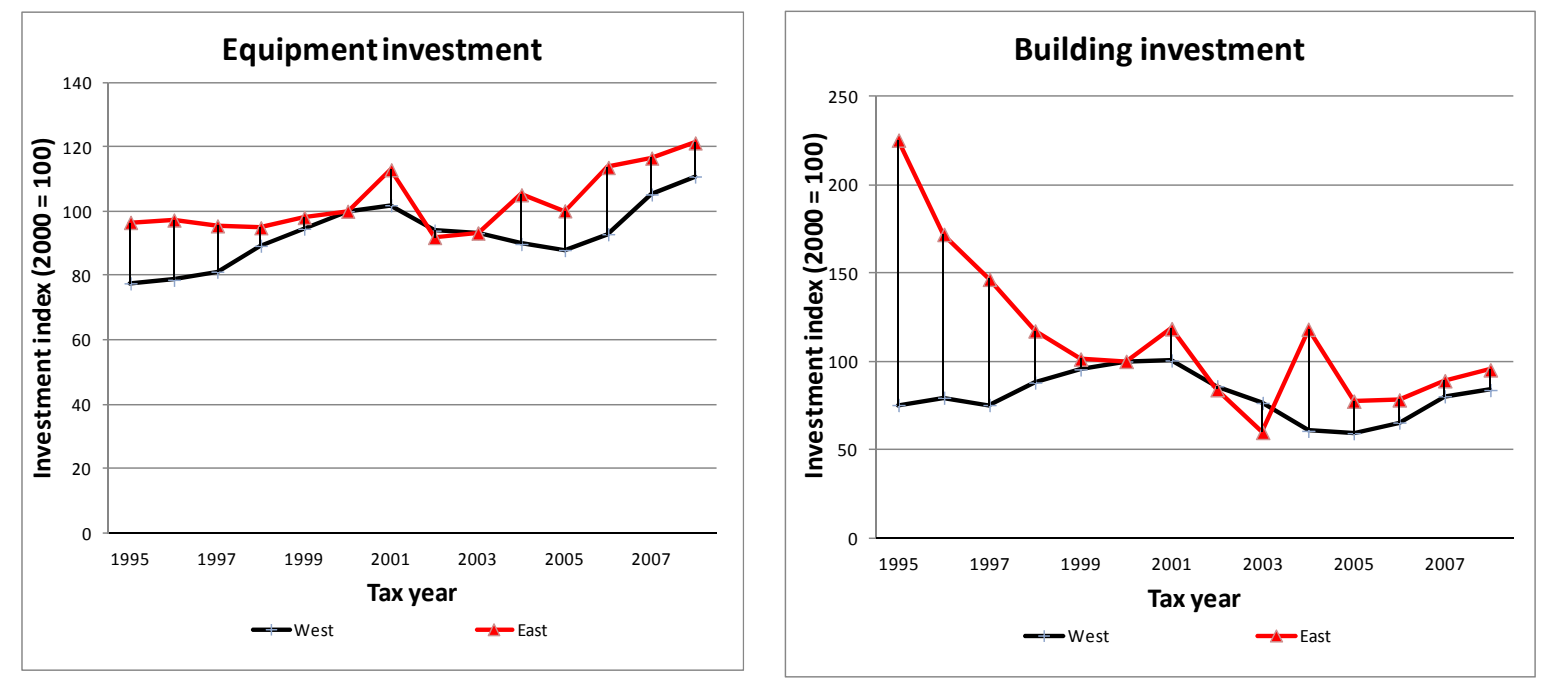

Note: Based on German Federal Statistical Office (2010). 
Figure 3: Residual plots
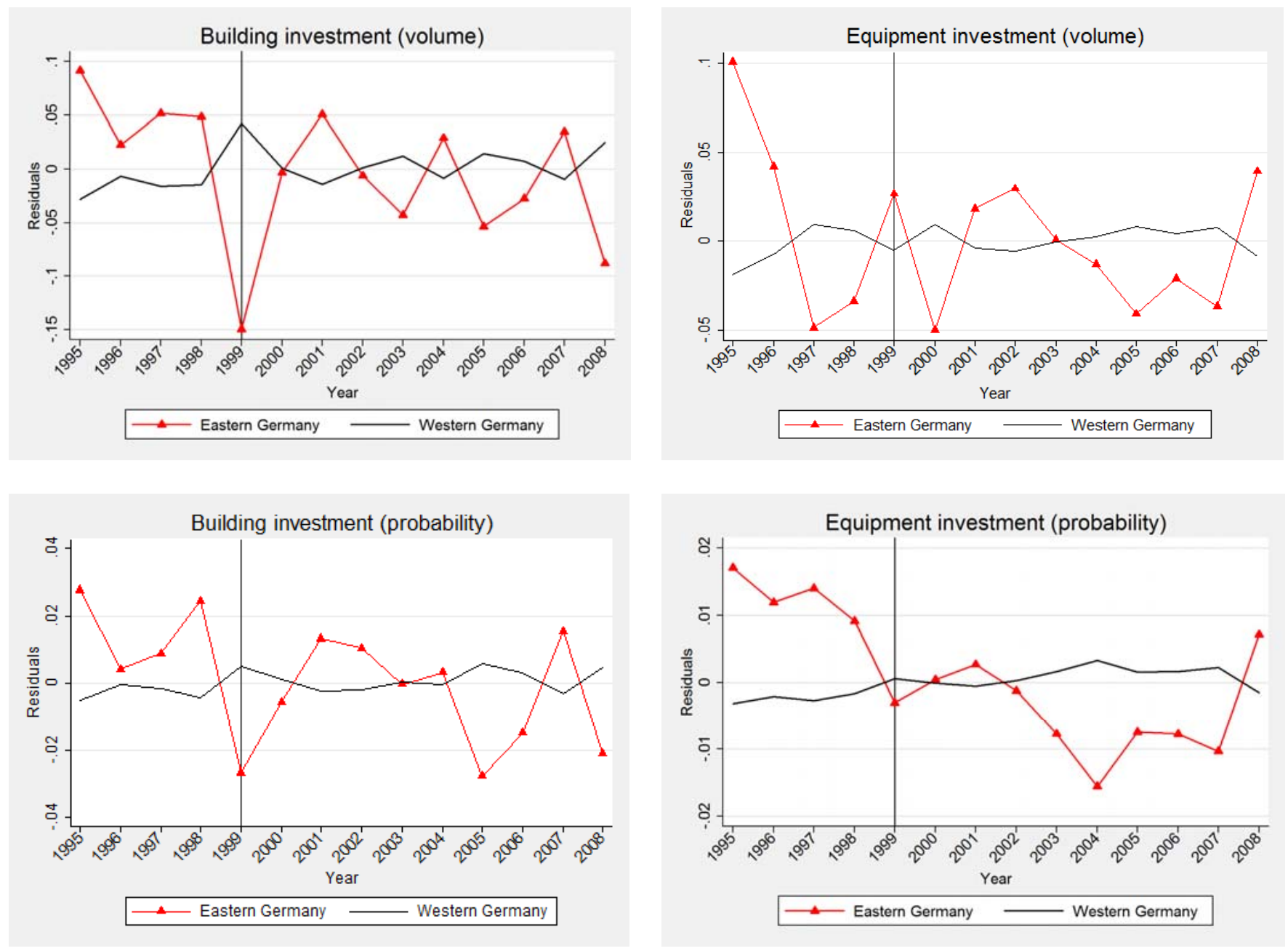

Notes: AFiD panel industrial units of the manufacturing industry; own calculations.

38 
Table 1: Regional investment subsidies 1995-2013

\begin{tabular}{|c|c|c|}
\hline & Development Area Law (DAL) & Investment Subsidy Law (ISL) \\
\hline Validity period & $\begin{array}{l}\text { 01.01.1991 to } 31.12 .1998 \\
\text { with amendments and revisions }\end{array}$ & $\begin{array}{l}01.01 .1991 \text { to } 31.12 .2013^{\text {a }} \\
\text { with amendments and revisions }\end{array}$ \\
\hline General rates & 50\% (1991-1996); 40\% (1997-1998) & $\begin{array}{l}\text { 12\% (1991 to June 1992); 8\% (July } 1992 \text { to June } \\
\text { 1994); } 5 \% \text { (July } 1994 \text { to 1998) }{ }^{\mathrm{c}} \text {; 10\% (1999); } \\
\text { 12.5\% (2000-2009); } 10 \%(2010) ; 7.5 \% \text { (2011); 5\% } \\
\text { (2012); } 2.5 \%(2013)^{\mathrm{b}}\end{array}$ \\
\hline Increased rates & N.A. & $\begin{array}{l}\text { + } 5 \% \text { (SME; } 1995 \text { to } 1998 \text { ); } \\
\times 2 \text { general rate for equipment investment (SME; } \\
1999 \text { to } 2013 \text { ); } \\
+2.5 \% \text { (border areas; } 2001 \text { to } 2009 \text { ) }\end{array}$ \\
\hline $\begin{array}{l}\text { Regional } \\
\text { specifications }\end{array}$ & N.A. & $\begin{array}{l}\text { Berlin: Reduced validity periods (Berlin West); } \\
\text { Reduced subsidy rates under certain conditions } \\
\text { (1996 to 2012) }\end{array}$ \\
\hline $\begin{array}{l}\text { Assessment } \\
\text { base }\end{array}$ & $\begin{array}{l}\text { Movable assets (excluding aircraft); Immovable } \\
\text { assets; Modernization of buildings }\end{array}$ & $\begin{array}{l}\text { New and movable assets (excluding low-grade } \\
\text { assets, aircraft, cars); New and immovable assets } \\
\text { (since 1999); Restriction to initial investments } \\
\text { (since 1999) }\end{array}$ \\
\hline $\begin{array}{l}\text { Formal } \\
\text { requirements }\end{array}$ & Tax return & Formal application \\
\hline
\end{tabular}


Table 2: Relative tax burden (in \%)

Large businesses

Small and medium businesses

\section{Group} $\begin{array}{lllllllllll}1995 & 1996 & 1997 & 1998 & 1999 & 2000 & 2001 & 2002 & 2003 & 2004 & 2005\end{array}$

$997 \quad 1998 \quad 19992000 \quad 2001 \quad 2002 \quad 20$

\section{New structures (initial investment)}

New structures (no initial investment)

Old structures (modernizations)
Fundable equipment (initial investmen $)$

$\begin{array}{llllllllllll}81.1 & 77.2 & 81.6 & 82.2 & 86.2 & 86.9 & 86.3 & 85.1 & 84.7 & 84.8 & 84.8\end{array}$

$\begin{array}{lllllllllll}81.1 & 77.2 & 81.6 & 82.2 & 98.3 & 98.3 & 98.1 & 98.4 & 98.4 & 98.4 & 98.3\end{array}$

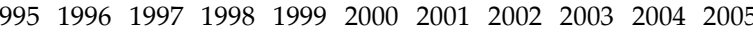

Fundable equipment (no initial investment)

$\begin{array}{lllllllllll}81.0 & 74.0 & 78.9 & 79.4 & 98.0 & 98.0 & 98.0 & 98.3 & 98.2 & 98.3 & 98.1\end{array}$

$\begin{array}{lllllllllll}83.3 & 86.2 & 88.6 & 88.7 & 82.5 & 81.2 & 81.6 & 81.6 & 81.0 & 81.5 & 81.8\end{array}$

$\begin{array}{lllllllllllll}83.3 & 86.2 & 88.6 & 88.7 & 90.9 & 91.3 & 92.3 & 99.5 & 99.5 & 99.6 & 99.5\end{array}$

Non-fundable equipment

\begin{tabular}{lllllllllllllllllllllllll}
94.4 & 95.0 & 97.4 & 97.6 & 99.4 & 99.4 & 99.4 & 99.5 & 99.5 & 99.6 & 99.5 & 94.4 & 95.0 & 97.4 & 97.6 & 99.4 & 99.4 & 99.4 & 99.5 & 99.5 & 99.6 & 99.5 \\
\hline
\end{tabular}

Relative tax burden for investments in Eastern Germany compared to Western Germany. The relevant years refer to the completion of an investment. 
Table 3: Descriptive statistics by region

\begin{tabular}{|c|c|c|c|}
\hline Panel A: GERMANY $(\mathrm{N}=574,188)$ & Mean & Std. Dev. & Median \\
\hline \multicolumn{4}{|l|}{ Real investments (thousand $€$ ) } \\
\hline Gross investment (1,000 Euro) & $1,118.39$ & $11,037.25$ & 112.42 \\
\hline Building investment (1,000 Euro) & 128.57 & $1,362.73$ & 0.00 \\
\hline Equipment investment (1,000 Euro) & 980.03 & $10,131.11$ & 100.96 \\
\hline Land investment (1,000 Euro) & 7.75 & 265.78 & 0.00 \\
\hline \multicolumn{4}{|c|}{ Fraction of establishments with positive investments (\%) } \\
\hline Gross investment & 86.69 & 33.97 & \\
\hline Equipment investment & 86.31 & 34.37 & \\
\hline Building investment & 20.84 & 40.62 & \\
\hline Land investment & 3.33 & 17.95 & \\
\hline \multicolumn{4}{|l|}{ Control variables } \\
\hline Large firm (>250 staff members) (\%) & 17.02 & 37.58 & \\
\hline Capital stock (1,000 Euro) & 5168.27 & $26,589.93$ & $1,642.54$ \\
\hline Revenue (1,000,000 Euro) & 31.26 & 305.84 & 6.14 \\
\hline Revenue per capital (\%) & 518.25 & $1,155.29$ & 376.45 \\
\hline Share of exports (\%) & 16.86 & 23.17 & 4.52 \\
\hline Share of manufacturing (\%) & 94.31 & 14.24 & 100.00 \\
\hline GDP per capita (1,000 Euro) & $25,262.40$ & $9,766.69$ & $23,275.00$ \\
\hline Population $(1,000)$ & 274.40 & 239.36 & 203.70 \\
\hline Unemployment rate (\%) & 10.39 & 4.60 & 9.20 \\
\hline
\end{tabular}


Table 3 cont.

Panel B: WEST(N=478,790)

Mean

Std. Dev.

Median

Real investments (thousand $€$ )

Gross investment (1,000 Euro)

$1,142.79$

$11,490.40$

114.94

Building investment (1,000 Euro)

124.77

$1,382.50$

0.00

Equipment investment (1,000 Euro)

8.05

$10,552.66$

104.78

Land investment (1,000 Euro)

287.50

0.00

Gross investment

Equipment investment

$86.91 \quad 33.73$

$86.56 \quad 34.11$

Building investment

$86.56-34.11$

Land investment

2.99

39.57

Control variables

Large firm (>250 staff members) (\%)

Capital stock (1,000 Euro)

Revenue (1,000,000 Euro)

Revenue per capital (\%)

Share of exports (\%)

Share of manufacturing (\%)

GDP per capita (1,000 Euro)

Population $(1,000)$

17.83

$5,268.68$

34.48

555.13

18.23

94.12

26,780.21

17.03

Unemployment rate (\%)

298.48

38.28

27,560.42

332.94

$1,244.80$

$1,614.46$

$1,244.80$
23.64

14.44

9,825.65

251.99

6.69

406.98

6.68

100.00

8.86

244.43

8.40 
Table 3 cont.

Panel C: EAST $(\mathrm{N}=95,398)$

Mean

Std. Dev.

Median

Real investments (thousand $€$ )

Gross investment (1,000 Euro)

Building investment (1,000 Euro)

995.97

147.60

Equipment investment (1,000 Euro)

838.94

$8,400.48$

99.50

Land investment (1,000 Euro)

6.23

$1,258.68$

0.00

Fraction of establishments with positive investments (\%)

Gross investment

Equipment investment

85.59

85.07

7671.75

82.48

Building investment

85.07
27.87

101.64

0.00

Cond investment

5.06

35.12

Control variables

Large firm (>250 staff members) (\%)

Capital stock (1,000 Euro)

12.94

Revenue (1,000,000 Euro)

$4,664.33$

15.10

Revenue per capital (\%)

Share of exports (\%)

Share of manufacturing (\%)

GDP per capita (1,000 Euro)

Population $(1,000)$

333.17

10.01

95.28

$17,644.72$

153.55

35.64

44.84

21.92

18.06

33.57

$21,046.88$

79.61

464.09

3.98

19.25

228.20

13.10

100.00

$4,472.11$

$16,606.00$

Notes: AFiD panel industrial units of the manufacturing industry; own calculations. 
Table 4a: Standard model (investment volume)

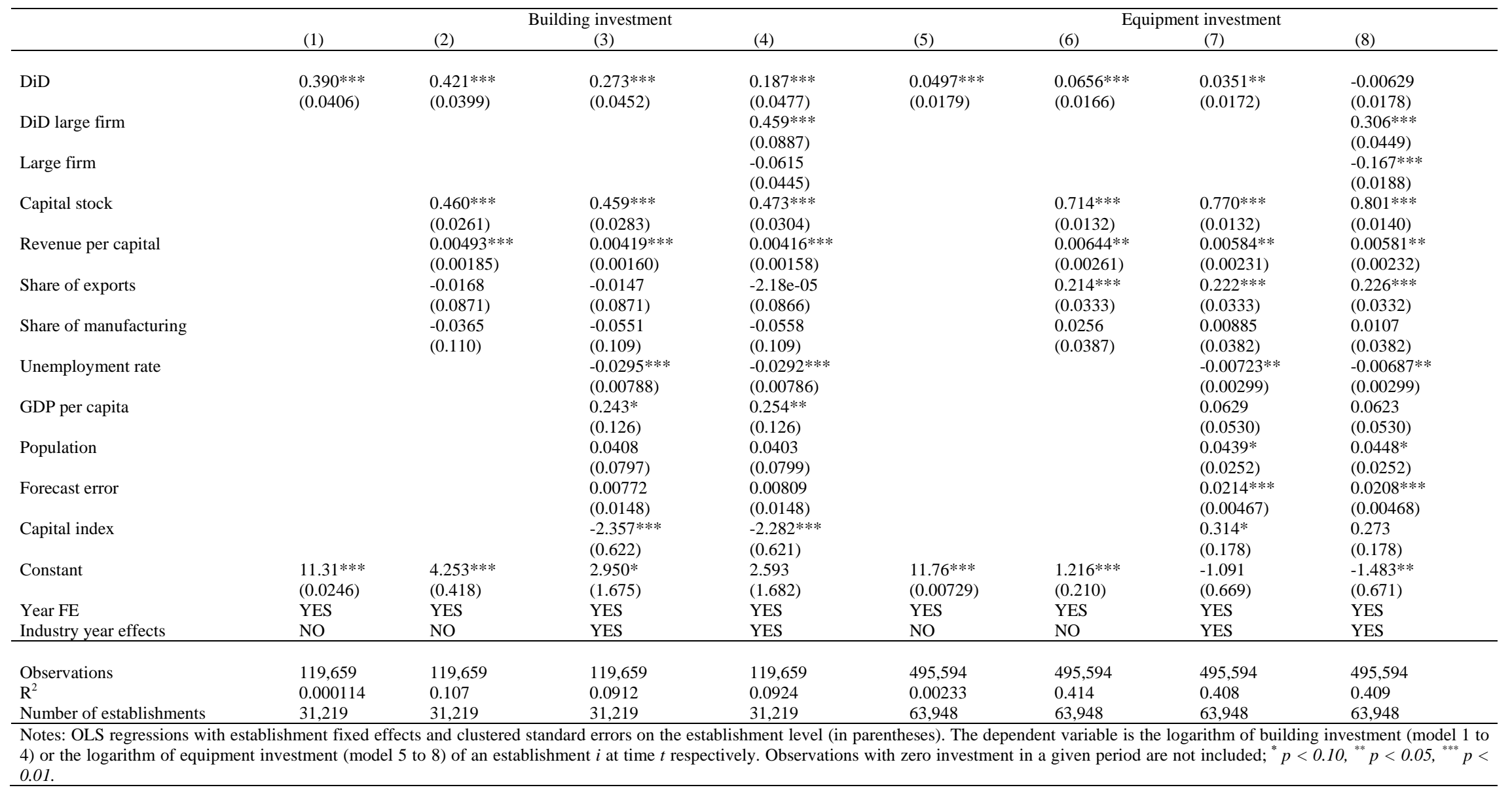


Table 4b: Standard model (investment probability)

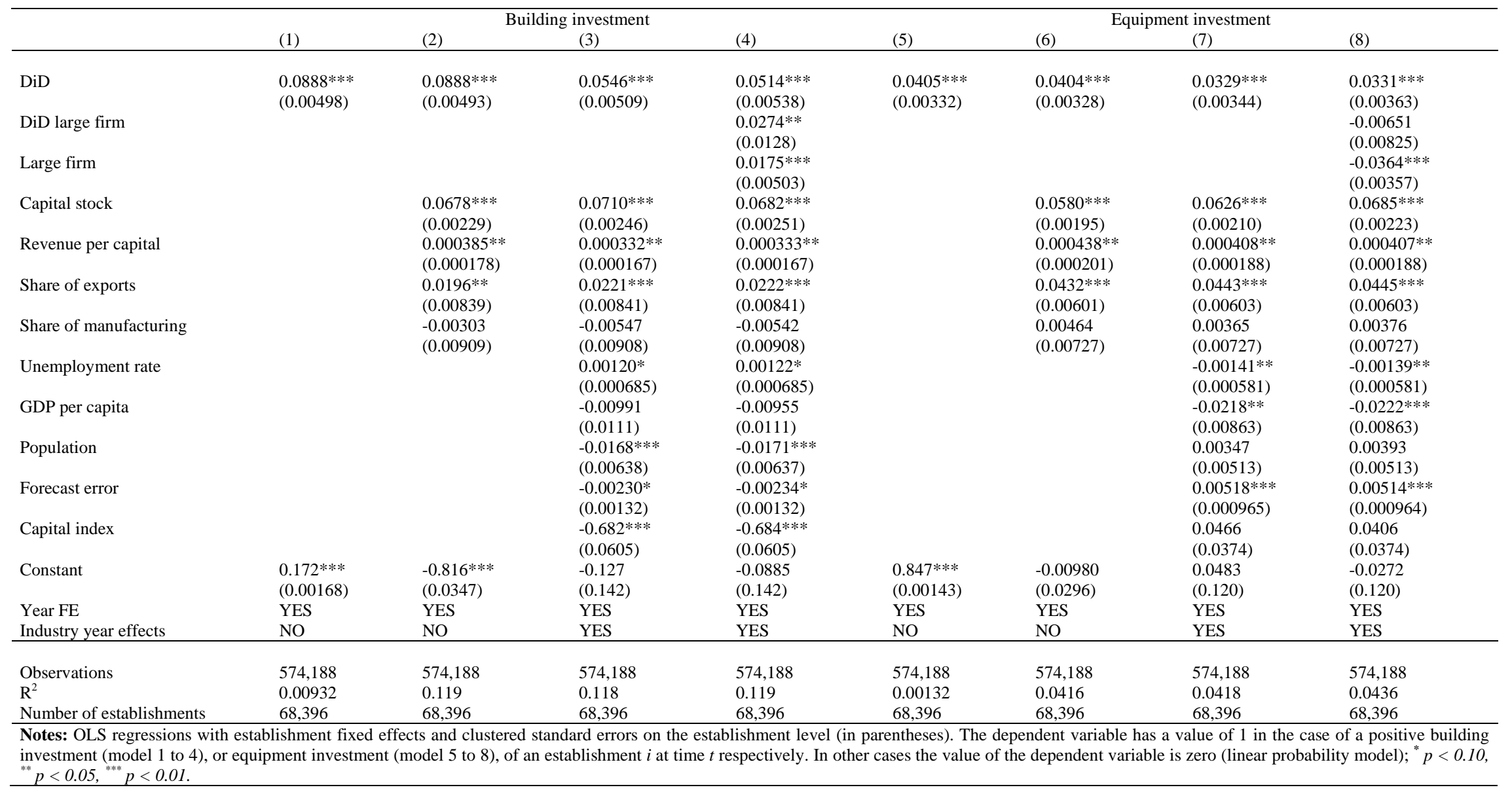


Table 5a: Extended model (investment volume)

\begin{tabular}{|c|c|c|c|c|c|c|c|c|}
\hline & & & nvestment & & & Equ & investment & \\
\hline DiD & $\begin{array}{l}0.238 * * * \\
(0.0820)\end{array}$ & $\begin{array}{l}0.250^{* * *} \\
(0.0472)\end{array}$ & $\begin{array}{l}0.217^{* * *} \\
(0.0827)\end{array}$ & $\begin{array}{l}0.161^{*} \\
(0.0831)\end{array}$ & $\begin{array}{l}0.163 * * * \\
(0.0238)\end{array}$ & $\begin{array}{l}0.0143 \\
(0.0177)\end{array}$ & $\begin{array}{l}0.141 * * * \\
(0.0242)\end{array}$ & $\begin{array}{l}0.120 * * * \\
(0.0243)\end{array}$ \\
\hline DiD 1997/98 & $\begin{array}{l}-0.0773 \\
(0.0599)\end{array}$ & & $\begin{array}{l}-0.0796 \\
(0.0599)\end{array}$ & $\begin{array}{l}-0.0782 \\
(0.0598)\end{array}$ & $\begin{array}{l}-0.176^{* * * *} \\
(0.0214)\end{array}$ & & $\begin{array}{l}-0.177^{* * *} \\
(0.0214)\end{array}$ & $\begin{array}{l}-0.176^{* * *} \\
(0.0213)\end{array}$ \\
\hline DiD 1999 & $\begin{array}{l}-0.194^{* *} \\
(0.0876)\end{array}$ & & $\begin{array}{l}-0.194 * * \\
(0.0876)\end{array}$ & $\begin{array}{l}-0.189 * * \\
(0.0876)\end{array}$ & $\begin{array}{l}0.0922 * * * \\
(0.0243)\end{array}$ & & $\begin{array}{l}0.0897^{* * *} \\
(0.0243)\end{array}$ & $\begin{array}{l}0.0901 * * * \\
(0.0243)\end{array}$ \\
\hline DiD group & & $\begin{array}{l}0.133 \\
(0.0930)\end{array}$ & $\begin{array}{l}0.138 \\
(0.0931)\end{array}$ & $\begin{array}{l}-0.0798 \\
(0.103)\end{array}$ & & $\begin{array}{l}0.107^{* *} \\
(0.0454)\end{array}$ & $\begin{array}{l}0.112 * * \\
(0.0454)\end{array}$ & $\begin{array}{l}4.90 \mathrm{e}-06 \\
(0.0497)\end{array}$ \\
\hline Group & & $\begin{array}{l}-0.0688^{*} \\
(0.0361)\end{array}$ & $\begin{array}{l}-0.0686^{*} \\
(0.0361)\end{array}$ & $\begin{array}{l}-0.0550 \\
(0.0368)\end{array}$ & & $\begin{array}{l}-0.0653^{* * * *} \\
(0.0145)\end{array}$ & $\begin{array}{l}-0.0646^{* * *} \\
(0.0145)\end{array}$ & $\begin{array}{l}-0.0368 * * \\
(0.0148)\end{array}$ \\
\hline DiD large firm & & & & $\begin{array}{l}0.488^{* * * *} \\
(0.0988)\end{array}$ & & & & $\begin{array}{l}0.305^{* * *} \\
(0.0492)\end{array}$ \\
\hline Large firm & & & & $\begin{array}{l}-0.0472 \\
(0.0454)\end{array}$ & & & & $\begin{array}{l}-0.157 * * * \\
(0.0191)\end{array}$ \\
\hline Capital stock & $\begin{array}{l}0.459 * * * \\
(0.0283)\end{array}$ & $\begin{array}{l}0.460 * * * \\
(0.0283)\end{array}$ & $\begin{array}{l}0.460 * * * \\
(0.0283)\end{array}$ & $\begin{array}{l}0.470^{* * *} \\
(0.0305)\end{array}$ & $\begin{array}{l}0.773^{* * *} \\
(0.0132)\end{array}$ & $\begin{array}{l}0.770 * * * \\
(0.0132)\end{array}$ & $\begin{array}{l}0.772 * * * \\
(0.0132)\end{array}$ & $\begin{array}{l}0.801^{* * *} \\
(0.0141)\end{array}$ \\
\hline Revenue per capital & $\begin{array}{l}0.00420^{* * *} \\
(0.00160)\end{array}$ & $\begin{array}{l}0.00418^{* * *} \\
(0.00160)\end{array}$ & $\begin{array}{l}0.00419 * * * \\
(0.00160)\end{array}$ & $\begin{array}{l}0.00416^{* * *} \\
(0.00158)\end{array}$ & $\begin{array}{l}0.00584^{* *} \\
(0.00231)\end{array}$ & $\begin{array}{l}0.00583^{* *} \\
(0.00231)\end{array}$ & $\begin{array}{l}0.00583^{* *} \\
(0.00231)\end{array}$ & $\begin{array}{l}0.00581^{* *} \\
(0.00232)\end{array}$ \\
\hline Share of exports & $\begin{array}{l}-0.0156 \\
(0.0871)\end{array}$ & $\begin{array}{l}-0.00883 \\
(0.0869)\end{array}$ & $\begin{array}{l}-0.00971 \\
(0.0869)\end{array}$ & $\begin{array}{l}0.00355 \\
(0.0865)\end{array}$ & $\begin{array}{l}0.222 * * * \\
(0.0333)\end{array}$ & $\begin{array}{l}0.225^{* * *} \\
(0.0333)\end{array}$ & $\begin{array}{l}0.225 * * * \\
(0.0332)\end{array}$ & $\begin{array}{l}0.228 * * * \\
(0.0332)\end{array}$ \\
\hline Share of manufacturing & $\begin{array}{l}-0.0561 \\
(0.109)\end{array}$ & $\begin{array}{l}-0.0523 \\
(0.109)\end{array}$ & $\begin{array}{l}-0.0533 \\
(0.109)\end{array}$ & $\begin{array}{l}-0.0552 \\
(0.109)\end{array}$ & $\begin{array}{l}0.00984 \\
(0.0382)\end{array}$ & $\begin{array}{l}0.00952 \\
(0.0382)\end{array}$ & $\begin{array}{l}0.0105 \\
(0.0382)\end{array}$ & $\begin{array}{l}0.0120 \\
(0.0382)\end{array}$ \\
\hline GDP per capita & $\begin{array}{l}0.261^{* *} \\
(0.126)\end{array}$ & $\begin{array}{l}0.243^{*} \\
(0.126)\end{array}$ & $\begin{array}{l}0.262 * * \\
(0.126)\end{array}$ & $\begin{array}{l}0.274^{* *} \\
(0.126)\end{array}$ & $\begin{array}{l}0.0895 * \\
(0.0534)\end{array}$ & $\begin{array}{l}0.0635 \\
(0.0530)\end{array}$ & $\begin{array}{l}0.0898^{*} \\
(0.0534)\end{array}$ & $\begin{array}{l}0.0896^{*} \\
(0.0534)\end{array}$ \\
\hline Population & $\begin{array}{l}0.0461 \\
(0.0798)\end{array}$ & $\begin{array}{l}0.0442 \\
(0.0798)\end{array}$ & $\begin{array}{l}0.0496 \\
(0.0799)\end{array}$ & $\begin{array}{l}0.0482 \\
(0.0801)\end{array}$ & $\begin{array}{l}0.0412 \\
(0.0253)\end{array}$ & $\begin{array}{l}0.0453^{*} \\
(0.0252)\end{array}$ & $\begin{array}{l}0.0428^{*} \\
(0.0253)\end{array}$ & $\begin{array}{l}0.0428^{*} \\
(0.0252)\end{array}$ \\
\hline Forecast error & $\begin{array}{l}0.0170 \\
(0.0151)\end{array}$ & $\begin{array}{l}0.00825 \\
(0.0148)\end{array}$ & $\begin{array}{l}0.0176 \\
(0.0151)\end{array}$ & $\begin{array}{l}0.0174 \\
(0.0151)\end{array}$ & $\begin{array}{l}0.00658 \\
(0.00523)\end{array}$ & $\begin{array}{l}0.0211^{* * * *} \\
(0.00467)\end{array}$ & $\begin{array}{l}0.00654 \\
(0.00522)\end{array}$ & $\begin{array}{l}0.00601 \\
(0.00523)\end{array}$ \\
\hline Capital index & $\begin{array}{l}-3.371^{* * * *} \\
(0.888)\end{array}$ & $\begin{array}{l}-2.314^{* * * *} \\
(0.623)\end{array}$ & $\begin{array}{l}-3.321^{* * * *} \\
(0.889)\end{array}$ & $\begin{array}{l}-3.231^{* * * *} \\
(0.888)\end{array}$ & $\begin{array}{l}0.336^{*} \\
(0.183)\end{array}$ & $\begin{array}{l}0.292 \\
(0.178)\end{array}$ & $\begin{array}{l}0.311^{*} \\
(0.183)\end{array}$ & $\begin{array}{l}0.284 \\
(0.183)\end{array}$ \\
\hline Constant & $\begin{array}{l}3.240^{*} \\
(1.736)\end{array}$ & $\begin{array}{l}2.871^{*} \\
(1.675)\end{array}$ & $\begin{array}{l}3.150^{*} \\
(1.737)\end{array}$ & $\begin{array}{l}2.840 \\
(1.743)\end{array}$ & $\begin{array}{l}-1.328^{* *} \\
(0.673)\end{array}$ & $\begin{array}{l}-1.072 \\
(0.669)\end{array}$ & $\begin{array}{l}-1.308^{*} \\
(0.672)\end{array}$ & $\begin{array}{l}-1.689^{* *} \\
(0.675)\end{array}$ \\
\hline $\begin{array}{l}\text { Year FE } \\
\text { Industry year effects }\end{array}$ & $\begin{array}{l}\text { YES } \\
\text { YES }\end{array}$ & $\begin{array}{l}\text { YES } \\
\text { YES }\end{array}$ & $\begin{array}{l}\text { YES } \\
\text { YES }\end{array}$ & $\begin{array}{l}\text { YES } \\
\text { YES }\end{array}$ & $\begin{array}{l}\text { YES } \\
\text { YES }\end{array}$ & $\begin{array}{l}\text { YES } \\
\text { YES }\end{array}$ & $\begin{array}{l}\text { YES } \\
\text { YES }\end{array}$ & $\begin{array}{l}\text { YES } \\
\text { YES }\end{array}$ \\
\hline Observations & 119,659 & 119,659 & 119,659 & 119,659 & 495,594 & 495,594 & 495,594 & 495,594 \\
\hline $\mathrm{R}^{2}$ & 0.0898 & 0.0919 & 0.0905 & 0.0914 & 0.408 & 0.409 & 0.408 & 0.409 \\
\hline Number of establishments & 31,219 & 31,219 & 31,219 & 31,219 & 63,948 & 63,948 & 63,948 & 63,948 \\
\hline
\end{tabular}


Table 5b: Extended model (investment probability)

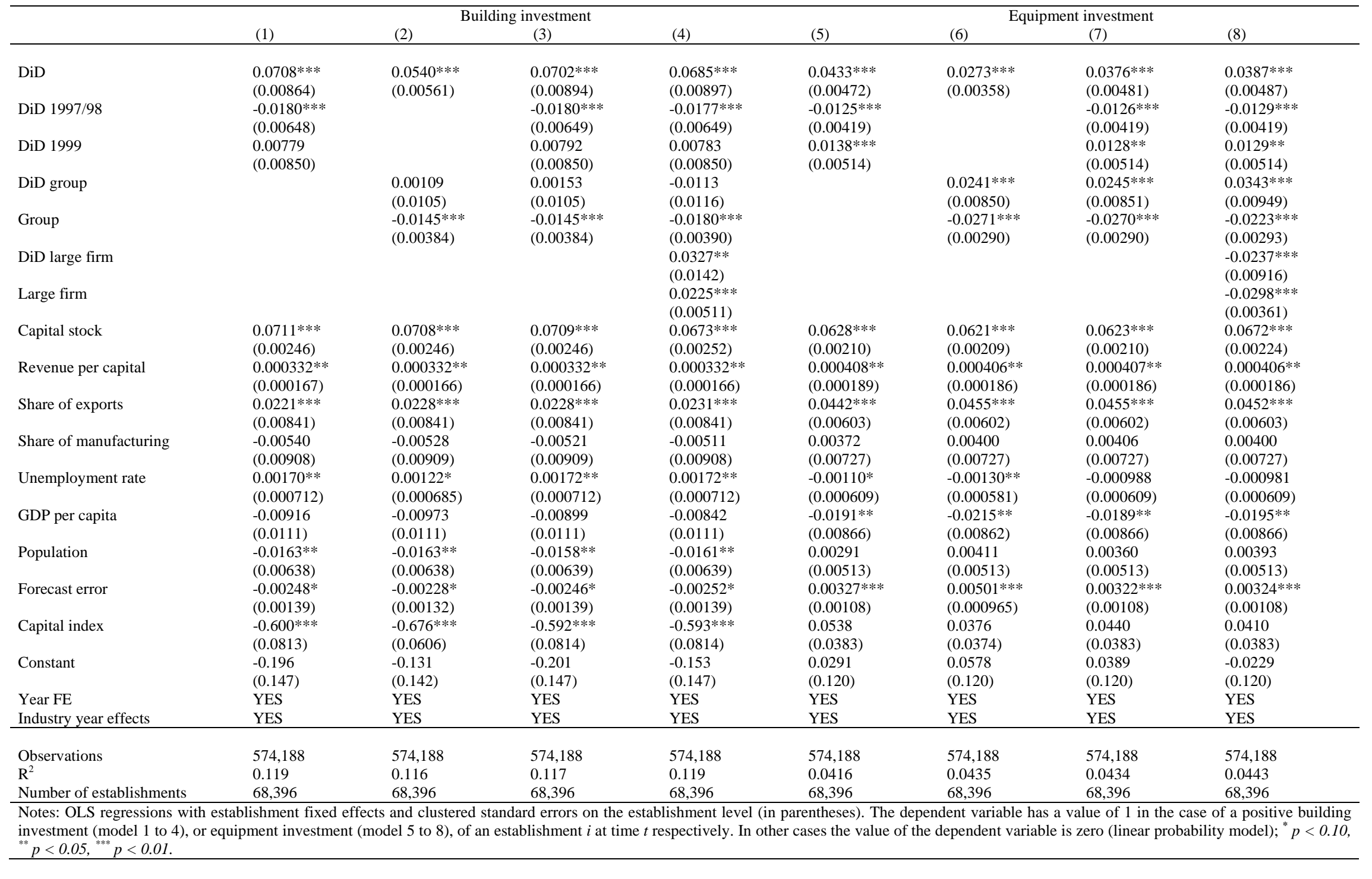


Table 6: Building price indices (manufacturing sector)

\begin{tabular}{lrrrrrrrrrrrrrr} 
Survey year & 1995 & 1996 & 1997 & 1998 & 1999 & 2000 & 2001 & 2002 & 2003 & 2004 & 2005 & 2006 & 2007 & 2008 \\
\hline Index Eastern Germany & 97.9 & 98.1 & 97.3 & 96.3 & 95.0 & 94.7 & 94.1 & 94.3 & 95.3 & 97.8 & 100.0 & 102.5 & 110.4 & 114.6 \\
Index Western Germany & 93.9 & 94.2 & 93.9 & 94.5 & 94.7 & 95.9 & 96.7 & 96.9 & 97.2 & 98.4 & 100.0 & 102.3 & 109.6 & 113.6 \\
\hline
\end{tabular}

Weighted average building price indices for the manufacturing sector in Eastern Germany and Western Germany. The indices are calculated from GDP-weighted price indices in the manufacturing sector as reported by the Statistical State Offices in Western Germany (Baden-Württemberg, Bavaria, Hessen, Lower Saxony, North Rhine-Westphalia and Saarland) and Eastern Germany (Brandenburg, Saxony, Saxony-Anhalt and Thuringia). Due to the specific economic and legal situation in Berlin, we do not account for price developments in that area. There are no corresponding price indices available for Bremen, Hamburg, Mecklenburg-West Pomerania, Rhineland-Palatinate or Schleswig-Holstein. 
Table 7: Building investment volume without state-level price adjustment

\begin{tabular}{|c|c|c|c|c|c|c|c|c|}
\hline & (1) & (2) & $\begin{array}{l}\text { investment } \\
\text { (3) }\end{array}$ & (4) & (5) & (6) & $\begin{array}{l}\text { investment } \\
\text { (7) }\end{array}$ & (8) \\
\hline DiD & $\begin{array}{l}0.434 * * * \\
(0.0405)\end{array}$ & $\begin{array}{l}0.465^{* * *} \\
(0.0398)\end{array}$ & $\begin{array}{l}0.309 * * * \\
(0.0452)\end{array}$ & $\begin{array}{l}0.225^{* * *} \\
(0.0477)\end{array}$ & $\begin{array}{l}0.0497^{* * *} \\
(0.0179)\end{array}$ & $\begin{array}{l}0.0656^{* * *} \\
(0.0166)\end{array}$ & $\begin{array}{l}0.0351 * * \\
(0.0172)\end{array}$ & $\begin{array}{l}-0.00629 \\
(0.0178)\end{array}$ \\
\hline DiD large firm & & & & $\begin{array}{l}0.455^{* * *} \\
(0.0886)\end{array}$ & & & & $\begin{array}{l}0.306^{* * * *} \\
(0.0449)\end{array}$ \\
\hline Large firm & & & & $\begin{array}{l}-0.0608 \\
(0.0445)\end{array}$ & & & & $\begin{array}{l}-0.167 * * * \\
(0.0188)\end{array}$ \\
\hline Capital stock & & $\begin{array}{l}0.459 * * * \\
(0.0261)\end{array}$ & $\begin{array}{l}0.459 * * * \\
(0.0283)\end{array}$ & $\begin{array}{l}0.473 * * * \\
(0.0304)\end{array}$ & & $\begin{array}{l}0.714 * * * \\
(0.0132)\end{array}$ & $\begin{array}{l}0.770 * * * \\
(0.0132)\end{array}$ & $\begin{array}{l}0.801^{* * *} \\
(0.0140)\end{array}$ \\
\hline Revenue per capital & & $\begin{array}{l}0.00493^{* * *} \\
(0.00185)\end{array}$ & $\begin{array}{l}0.00419 * * * \\
(0.00160)\end{array}$ & $\begin{array}{l}0.00416^{* * *} \\
(0.00158)\end{array}$ & & $\begin{array}{l}0.00644^{* *} \\
(0.00261)\end{array}$ & $\begin{array}{l}0.00584^{* *} \\
(0.00231)\end{array}$ & $\begin{array}{l}0.00581 * * \\
(0.00232)\end{array}$ \\
\hline Share of exports & & $\begin{array}{l}-0.0174 \\
(0.0871)\end{array}$ & $\begin{array}{l}-0.0153 \\
(0.0870)\end{array}$ & $\begin{array}{l}-0.000705 \\
(0.0866)\end{array}$ & & $\begin{array}{l}0.214^{* * *} \\
(0.0333)\end{array}$ & $\begin{array}{l}0.222^{* * *} \\
(0.0333)\end{array}$ & $\begin{array}{l}0.226^{* * *} \\
(0.0332)\end{array}$ \\
\hline Share of manufacturing & & $\begin{array}{l}-0.0382 \\
(0.110)\end{array}$ & $\begin{array}{l}-0.0570 \\
(0.109)\end{array}$ & $\begin{array}{l}-0.0576 \\
(0.109)\end{array}$ & & $\begin{array}{l}0.0256 \\
(0.0387)\end{array}$ & $\begin{array}{l}0.00885 \\
(0.0382)\end{array}$ & $\begin{array}{l}0.0107 \\
(0.0382)\end{array}$ \\
\hline Unemployment rate & & & $\begin{array}{l}-0.0310^{* * *} \\
(0.00788)\end{array}$ & $\begin{array}{l}-0.0307 * * * \\
(0.00786)\end{array}$ & & & $\begin{array}{l}-0.00723^{* *} \\
(0.00299)\end{array}$ & $\begin{array}{l}-0.00687 * * \\
(0.00299)\end{array}$ \\
\hline GDP per capita & & & $\begin{array}{l}0.245^{*} \\
(0.126)\end{array}$ & $\begin{array}{l}0.256^{* *} \\
(0.126)\end{array}$ & & & $\begin{array}{l}0.0629 \\
(0.0530)\end{array}$ & $\begin{array}{l}0.0623 \\
(0.0530)\end{array}$ \\
\hline Population & & & $\begin{array}{l}0.0330 \\
(0.0797)\end{array}$ & $\begin{array}{l}0.0325 \\
(0.0799)\end{array}$ & & & $\begin{array}{l}0.0439^{*} \\
(0.0252)\end{array}$ & $\begin{array}{l}0.0448^{*} \\
(0.0252)\end{array}$ \\
\hline Forecast error & & & $\begin{array}{l}0.0122 \\
(0.0148)\end{array}$ & $\begin{array}{l}0.0126 \\
(0.0148)\end{array}$ & & & $\begin{array}{l}0.0214^{* * * *} \\
(0.00467)\end{array}$ & $\begin{array}{l}0.0208^{* * *} \\
(0.00468)\end{array}$ \\
\hline Constant & & & & & & & $\begin{array}{l}0.314^{*} \\
(0.178)\end{array}$ & $\begin{array}{l}0.273 \\
(0.178)\end{array}$ \\
\hline $\begin{array}{l}\text { Year FE } \\
\text { Industry year effects }\end{array}$ & $\begin{array}{l}11.38^{* * *} \\
(0.0246) \\
\end{array}$ & $\begin{array}{l}4.328 * * * \\
(0.418) \\
\end{array}$ & $\begin{array}{l}3.111 * \\
(1.675) \\
\end{array}$ & $\begin{array}{l}2.757 \\
(1.682) \\
\end{array}$ & $\begin{array}{l}11.76^{* * *} \\
(0.00729) \\
\end{array}$ & $\begin{array}{l}1.216^{* * *} \\
(0.210) \\
\end{array}$ & $\begin{array}{l}-1.091 \\
(0.669) \\
\end{array}$ & $\begin{array}{l}-1.483^{* *} \\
(0.671) \\
\end{array}$ \\
\hline Observations & 119,659 & 119,659 & 119,659 & 119,659 & 119,659 & 119,659 & 119,659 & 119,659 \\
\hline & 0.000332 & 0.107 & 0.0918 & 0.0930 & 0.00233 & 0.414 & 0.408 & 0.409 \\
\hline Number of establishments & 31,219 & 31,219 & 31,219 & 31,219 & 31,219 & 31,219 & 31,219 & 31,219 \\
\hline
\end{tabular}


Table A.1: Alternative treatment and control groups

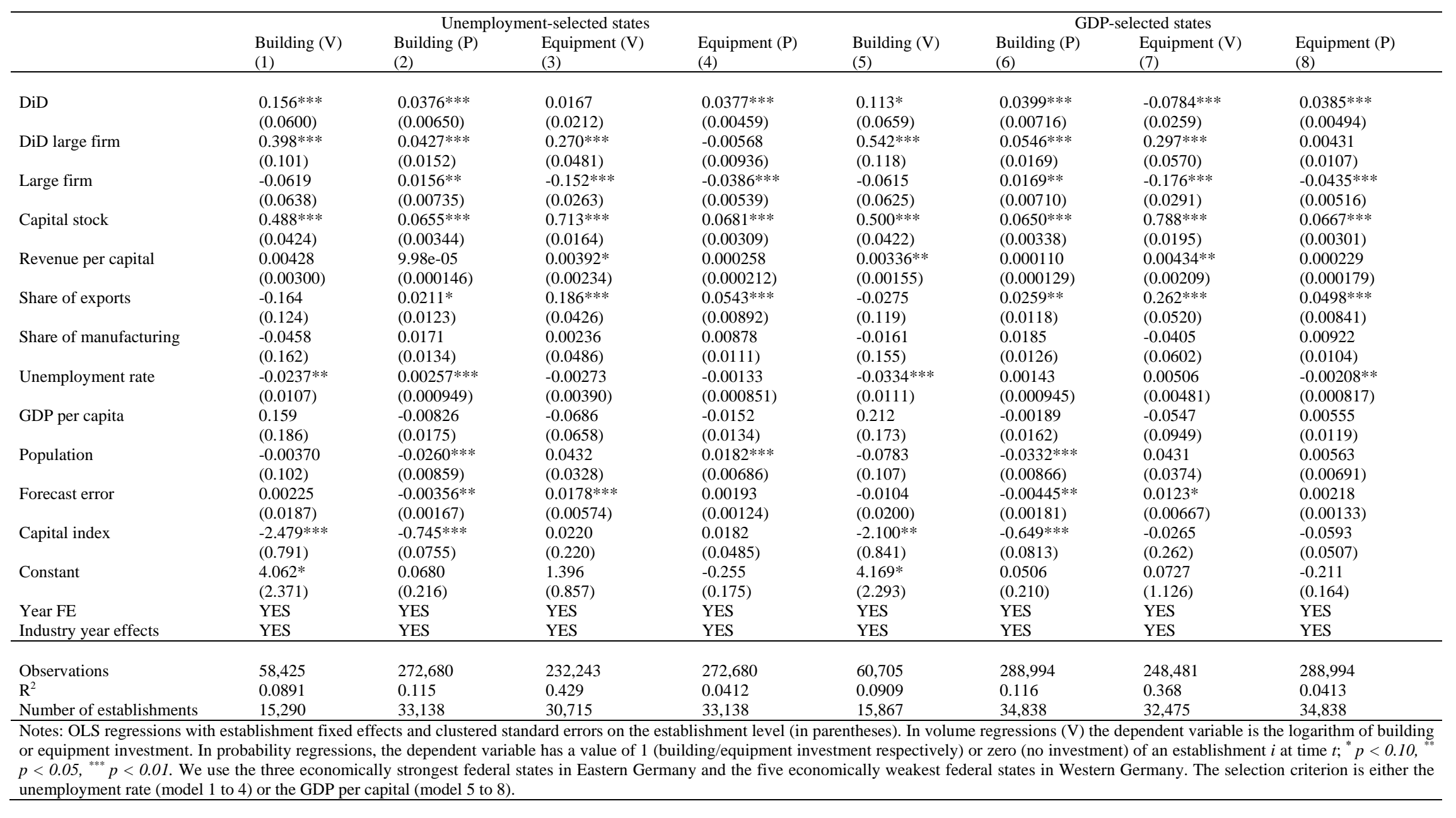


Table A.2: Mixed groups

\begin{tabular}{|c|c|c|c|c|c|c|c|c|}
\hline & \multicolumn{4}{|c|}{ Standard model for mixed groups } & \multicolumn{4}{|c|}{ Standard model without mixed groups } \\
\hline & $\begin{array}{l}\text { Building (V) } \\
(1)\end{array}$ & $\begin{array}{l}\text { Building }(\mathrm{P}) \\
(2)\end{array}$ & $\begin{array}{l}\text { Equipment (V) } \\
\text { (3) }\end{array}$ & $\begin{array}{l}\text { Equipment (P) } \\
\text { (4) }\end{array}$ & $\begin{array}{l}\text { Building (V) } \\
(5)\end{array}$ & $\begin{array}{l}\text { Building }(\mathrm{P}) \\
(6)\end{array}$ & $\begin{array}{l}\text { Equipment (V) } \\
\text { (7) }\end{array}$ & $\begin{array}{l}\text { Equipment (P) } \\
(8)\end{array}$ \\
\hline DiD & $\begin{array}{l}-0.116 \\
(0.192)\end{array}$ & $\begin{array}{l}0.0280^{*} \\
(0.0156)\end{array}$ & $\begin{array}{l}0.103 \\
(0.0803)\end{array}$ & $\begin{array}{l}0.0247 * \\
(0.0143)\end{array}$ & $\begin{array}{l}0.211^{* * *} \\
(0.0504)\end{array}$ & $\begin{array}{l}0.0487 * * * \\
(0.00587)\end{array}$ & $\begin{array}{l}-0.0179 \\
(0.0181)\end{array}$ & $\begin{array}{l}0.0320^{* * *} \\
(0.00375)\end{array}$ \\
\hline DiD large & $\begin{array}{l}0.357^{*} \\
(0.204)\end{array}$ & $\begin{array}{l}0.0432 * * \\
(0.0194)\end{array}$ & $\begin{array}{l}0.0994 \\
(0.0913)\end{array}$ & $\begin{array}{l}0.00754 \\
(0.0173)\end{array}$ & $\begin{array}{l}0.582 * * * \\
(0.122)\end{array}$ & $\begin{array}{l}0.0487 * * \\
(0.0218)\end{array}$ & $\begin{array}{l}0.417 * * * \\
(0.0593)\end{array}$ & $\begin{array}{l}-0.0384 * * * \\
(0.00886)\end{array}$ \\
\hline Large firm & $\begin{array}{l}0.153 \\
(0.170)\end{array}$ & $\begin{array}{l}-0.00989 \\
(0.0122)\end{array}$ & $\begin{array}{l}-0.193 * * * \\
(0.0636)\end{array}$ & $\begin{array}{l}-0.0105 \\
(0.0113)\end{array}$ & $\begin{array}{l}-0.0523 \\
(0.0505)\end{array}$ & $\begin{array}{l}0.0240 * * * \\
(0.00599)\end{array}$ & $\begin{array}{l}-0.166 * * * \\
(0.0207)\end{array}$ & $\begin{array}{l}-0.0417 * * * \\
(0.00383)\end{array}$ \\
\hline Capital stock & $\begin{array}{l}0.322 * * * \\
(0.0865)\end{array}$ & $\begin{array}{l}0.0457^{* * *} \\
(0.00665)\end{array}$ & $\begin{array}{l}0.576 * * * \\
(0.0389)\end{array}$ & $\begin{array}{l}0.0360 * * * \\
(0.00628)\end{array}$ & $\begin{array}{l}0.501 * * * \\
(0.0340)\end{array}$ & $\begin{array}{l}0.0716^{* * * *} \\
(0.00277)\end{array}$ & $\begin{array}{l}0.836 * * * \\
(0.0149)\end{array}$ & $\begin{array}{l}0.0743 * * * \\
(0.00244)\end{array}$ \\
\hline Revenue per capital & $\begin{array}{l}-0.00210 \\
(0.00245)\end{array}$ & $\begin{array}{l}0.000128 \\
(0.000341)\end{array}$ & $\begin{array}{l}0.00627 * * * \\
(0.00165)\end{array}$ & $\begin{array}{l}0.000237 \\
(0.000286)\end{array}$ & $\begin{array}{l}0.00508^{* *} \\
(0.00199)\end{array}$ & $\begin{array}{l}0.000356^{*} \\
(0.000190)\end{array}$ & $\begin{array}{l}0.00554^{* *} \\
(0.00250)\end{array}$ & $\begin{array}{l}0.000396^{*} \\
(0.000204)\end{array}$ \\
\hline Share of exports & $\begin{array}{l}-0.286 \\
(0.267)\end{array}$ & $\begin{array}{l}0.0575^{* *} \\
(0.0293)\end{array}$ & $\begin{array}{l}0.217^{*} \\
(0.114)\end{array}$ & $\begin{array}{l}0.0448^{* *} \\
(0.0219)\end{array}$ & $\begin{array}{l}0.0297 \\
(0.0953)\end{array}$ & $\begin{array}{l}0.0187 * * \\
(0.00875)\end{array}$ & $\begin{array}{l}0.222 * * * \\
(0.0352)\end{array}$ & $\begin{array}{l}0.0424^{* * *} \\
(0.00634)\end{array}$ \\
\hline Share of manufacturing & $\begin{array}{l}-0.181 \\
(0.340)\end{array}$ & $\begin{array}{l}-0.0299 \\
(0.0251)\end{array}$ & $\begin{array}{l}0.120 \\
(0.106)\end{array}$ & $\begin{array}{l}-0.0192 \\
(0.0208)\end{array}$ & $\begin{array}{l}-0.0305 \\
(0.119)\end{array}$ & $\begin{array}{l}-0.000599 \\
(0.00971)\end{array}$ & $\begin{array}{l}0.00367 \\
(0.0413)\end{array}$ & $\begin{array}{l}0.00710 \\
(0.00787)\end{array}$ \\
\hline Unemployment rate & $\begin{array}{l}-0.0669 * * * \\
(0.0217)\end{array}$ & $\begin{array}{l}0.00134 \\
(0.00191)\end{array}$ & $\begin{array}{l}-0.0294^{* * *} \\
(0.00988)\end{array}$ & $\begin{array}{l}-0.00302 * \\
(0.00178)\end{array}$ & $\begin{array}{l}-0.0233^{* * *} \\
(0.00869)\end{array}$ & $\begin{array}{l}0.00128^{*} \\
(0.000744)\end{array}$ & $\begin{array}{l}-0.00350 \\
(0.00317)\end{array}$ & $\begin{array}{l}-0.00140^{* *} \\
(0.000619)\end{array}$ \\
\hline GDP per capita & $\begin{array}{l}0.0256 \\
(0.384)\end{array}$ & $\begin{array}{l}-0.0143 \\
(0.0273)\end{array}$ & $\begin{array}{l}-0.141 \\
(0.152)\end{array}$ & $\begin{array}{l}-0.0332 \\
(0.0266)\end{array}$ & $\begin{array}{l}0.283^{* *} \\
(0.136)\end{array}$ & $\begin{array}{l}-0.00731 \\
(0.0120)\end{array}$ & $\begin{array}{l}0.106 * \\
(0.0575)\end{array}$ & $\begin{array}{l}-0.0209 * * \\
(0.00918)\end{array}$ \\
\hline Population & $\begin{array}{l}0.310 \\
(0.208)\end{array}$ & $\begin{array}{l}0.0281^{*} \\
(0.0146)\end{array}$ & $\begin{array}{l}0.0614 \\
(0.0685)\end{array}$ & $\begin{array}{l}0.0187 \\
(0.0135)\end{array}$ & $\begin{array}{l}-0.0324 \\
(0.0896)\end{array}$ & $\begin{array}{l}-0.0241^{* * *} \\
(0.00713)\end{array}$ & $\begin{array}{l}0.0350 \\
(0.0270)\end{array}$ & $\begin{array}{l}0.00477 \\
(0.00557)\end{array}$ \\
\hline Forecast error & $\begin{array}{l}-0.00897 \\
(0.0400)\end{array}$ & $\begin{array}{l}-0.00175 \\
(0.00308)\end{array}$ & $\begin{array}{l}0.00730 \\
(0.0139)\end{array}$ & $\begin{array}{l}0.00463 \\
(0.00283)\end{array}$ & $\begin{array}{l}0.00975 \\
(0.0163)\end{array}$ & $\begin{array}{l}-0.00343^{* *} \\
(0.00151)\end{array}$ & $\begin{array}{l}0.0208 * * * \\
(0.00498)\end{array}$ & $\begin{array}{l}0.00602 * * * \\
(0.00103)\end{array}$ \\
\hline Capital index & $\begin{array}{l}-3.216^{*} \\
(1.697)\end{array}$ & $\begin{array}{l}-0.330^{* *} \\
(0.140)\end{array}$ & $\begin{array}{l}-0.373 \\
(0.523)\end{array}$ & $\begin{array}{l}0.198^{*} \\
(0.105)\end{array}$ & $\begin{array}{l}-2.039 * * * \\
(0.688)\end{array}$ & $\begin{array}{l}-0.797 * * * \\
(0.0691)\end{array}$ & $\begin{array}{l}0.427^{* *} \\
(0.189)\end{array}$ & $\begin{array}{l}0.0499 \\
(0.0404)\end{array}$ \\
\hline Constant & $\begin{array}{l}4.870 \\
(4.925)\end{array}$ & $\begin{array}{l}-0.429 \\
(0.338)\end{array}$ & $\begin{array}{l}4.303^{* *} \\
(1.907)\end{array}$ & $\begin{array}{l}0.279 \\
(0.327)\end{array}$ & $\begin{array}{l}2.537 \\
(1.832)\end{array}$ & $\begin{array}{l}-0.00464 \\
(0.157)\end{array}$ & $\begin{array}{l}-2.433^{* * *} \\
(0.725)\end{array}$ & $\begin{array}{l}-0.149 \\
(0.131)\end{array}$ \\
\hline $\begin{array}{l}\text { Year FE } \\
\text { Industry year effects }\end{array}$ & $\begin{array}{l}\text { YES } \\
\text { YES }\end{array}$ & $\begin{array}{l}\text { YES } \\
\text { YES }\end{array}$ & $\begin{array}{l}\text { YES } \\
\text { YES }\end{array}$ & $\begin{array}{l}\text { YES } \\
\text { YES }\end{array}$ & $\begin{array}{l}\text { YES } \\
\text { YES }\end{array}$ & $\begin{array}{l}\text { YES } \\
\text { YES }\end{array}$ & $\begin{array}{l}\text { YES } \\
\text { YES }\end{array}$ & $\begin{array}{l}\text { YES } \\
\text { YES }\end{array}$ \\
\hline Observations & 12,182 & 49,676 & 41,111 & 49,676 & 107,477 & 524,512 & 454,483 & 524,512 \\
\hline $\mathrm{R}^{2}$ & 0.0931 & 0.136 & 0.554 & 0.0837 & 0.0911 & 0.115 & 0.387 & 0.0380 \\
\hline Number of establishments & 3,543 & 8,334 & 7,544 & 8,334 & 29,108 & 64,012 & 59,903 & 64,012 \\
\hline
\end{tabular}

